\title{
Does getting along matter? Tourist-tourist rapport in guided group activities
}

\author{
Linda W. Lee ${ }^{\mathrm{a}, \mathrm{b}, *}$, Edward Boon ${ }^{\mathrm{b}, \mathrm{c}}$, Ian P. McCarthy ${ }^{\mathrm{d}, \mathrm{e}}$ \\ ${ }^{a}$ Nottingham Business School, Nottingham Trent University, 50 Shakespeare Street, Nottingham, NG1 4FQ, UK \\ ${ }^{\mathrm{b}}$ Industrial Economics and Management, KTH Royal Institute of Technology, SE-100 44, Stockholm, Sweden \\ ${ }^{\mathrm{c}}$ Walker School of Business and Technology, Webster University Geneva, 15 Route de Collex, 1293 Bellevue, Switzerland \\ ${ }^{\mathrm{d}}$ Simon Fraser University, 500 Granville St., Vancouver, BC, V6C 1W6, Canada \\ ${ }^{\mathrm{e}}$ Luiss, Viale Romania, 32, 00197, Roma, Italy
}

\section{A R T I C L E I N F O}

\section{Keywords:}

rapport

tourist-tourist interactions

group services

guided group activities

service satisfaction

service congruity

group attentiveness

\begin{abstract}
A B S T R A C T
Guided group activities, where tourists consume with other tourists, are common and important. Although the tourism and services literature suggests customer-employee rapport impacts customer satisfaction, the composition and impact of tourist-tourist rapport in guided group activities have received minimal attention. We use a three-study mixed method approach to conceptualize and examine tourist-tourist rapport in guided group activities. Study 1 identifies two recognized dyadic dimensions of tourist-tourist rapport (enjoyable interaction and personal connection) and two new group-based dimensions (group attentiveness and service congruity). Study 2 (video experiment) and Study 3 (field experiment) find that enjoyable interaction and personal connection mediate the relationship between group attentiveness and service congruity with satisfaction. Thus, touristtourist rapport in a group context is more multidimensional and complex than previously conceptualized for customer-employee rapport and non-group contexts. Further, we find tourist-tourist rapport is a critical service factor such that high levels satisfy, while low levels dissatisfy.
\end{abstract}

\section{Introduction}

Many tourists participate in guided group activities, where someone leads or instructs a group of tourists. This batching and guiding of tourists offer economic (i.e., more affordable than doing it alone), secure (i.e., less risky than doing it alone), and sociable (i.e., greater opportunity to meet people) ways of experiencing. Guided group activities offer diverse experiences, including tours of cities, wineries, restaurants, and galleries (Stylianou-Lambert, 2011), recreational activities such as rafting and hiking (Arnould \& Price, 1993; Chhetri, Arrowsmith, \& Jackson, 2004), and educational activities such as cooking, photography, art, and language classes (Horng \& Tsai, 2010; Long, 2013).

In such group contexts, tourists consume the service with other tourists rather than just in the presence of other tourists. For example, a customer who goes to a restaurant as a single individual dines in the presence of other customers whose behaviors can impact service satisfaction (Cai, Lu, \& Gursoy, 2018; Lin, Gursoy, \& Zhang, 2020). In contrast, a tourist who participates in a half-day group food tour and travels, dines, and interacts with other tourists in the group, consumes the service with other tourists. In these group settings, the behavior of other tourists likely has even greater impact on the focal tourist, as they are engaged with each other and are together for long periods ( $\mathrm{Wu}$, 2007, 2008bib_Wu_2007bib_Wu_2008). Further, tourists are often expected to converse and collaborate to co-produce the group experience, which can play an integral role in value creation (Finsterwalder \& Kuppelwieser, 2011; Huang \& Hsu, 2009; Wu, 2007).

Despite the importance of tourists consuming with other tourists in group activities, there is limited research on this phenomenon. Prior research focuses on contexts where customers are consuming services in the presence of rather than with other customers in a group context (Grove \& Fisk, 1997). Consequently, the customer-customer interactions studied are dyadic rather than group-based, more superficial and shorter in duration than in group activities (e.g. river rafting trips and food tours) where there is more opportunity for tourists to interact (Arnould \& Price, 1993; Finsterwalder \& Kuppelwieser, 2011).

To help understand the makeup and consequences of tourist-tourist relationships in such groups, we suggest using the construct of rapport. Rapport is appropriate as it is developed from interpersonal

\footnotetext{
* Corresponding author. Nottingham Business School, Nottingham Trent University, 50 Shakespeare Street, Nottingham, NG1 4FQ, UK.

E-mail address: linda.lee@ntu.ac.uk (L.W. Lee).
} 
interactions based on trust and cooperation (Drolet \& Morris, 2000), and enjoyable interactions, shared feelings, and mutual attention between the people concerned (Gremler \& Gwinner, 2000; Kim \& Ok, 2010). Building upon prior research on dyadic customer-employee rapport in services, we examine two research questions. What are the important dimensions of tourist-tourist rapport in guided group activities? And, using these dimensions, as per the title of our paper: Does getting along with other tourists in guided group activities matter to satisfaction?

In addressing these research questions, we believe our study is novel and important for the following reasons. First, we advance the construct of rapport to examine tourist-tourist interactions within a group context. Typically, tourism and services research (Gremler \& Gwinner, 2000; Hyun \& Kim, 2014; Kim \& Baker, 2019) have focused on customer-employee rapport in non-group contexts. Second, we unpack the rapport construct into dimensions for both the group-based and the dyadic relationships in a guided group activity to understand how rapport's multidimensionality works to affect satisfaction. To develop, unpack, and test rapport in this way, we use a mixed method approach to collect, analyze, and combine the findings from one qualitative study (Study 1) and two experimental studies (Study 2 and Study 3).

Our paper proceeds as follows. In Section 2, we review the literature on the relevance of using the rapport construct to examine guided group activities, and we identify potential dimensions of tourist-tourist rapport in such contexts. In Section 3, we present our three-study mixed method approach. Study 1 qualitatively identifies two dyadic dimensions and two new group-based dimensions of tourist-tourist rapport for guided group activities. Study 2 examines these four dimensions through a video experiment of a food tasting tour. Study 3 complements and supports Study 2, using a tourist sample experiencing a real food tasting tour. Finally, we conclude with a discussion of the theoretical and practical implications of our research.

\section{Theoretical background}

\subsection{Guided group activities in tourism}

Guided group activities involve batching tourists together on a planned itinerary with a tour guide to lead the group. Prior research focuses on the role guides play in mediating the interactions among group members (Falter \& Hadwich, 2020; Huang, Hsu, \& Chan, 2010; Tsaur \& Lin, 2014). Differences in tourists' background and interests can sometimes lead to intragroup discord and even verbal or physical conflict (Tsaur, Cheng, \& Hong, 2019; Wu, 2007). Consequently, studies have examined the capabilities guides require to effectively facilitate interaction and resolve conflict among group members (Hansen \& Mossberg, 2017).

\subsection{Customer-customer interactions in services and tourism}

Services research has mostly examined customer-customer interactions in settings in which customers consume in the presence of other customers (e.g., restaurants, retail stores, queues). Even though these customer-customer interactions are short and superficial, positive interactions enhance the perceived service experience (Altinay, Song, Madanoglus, \& Wang, 2019; Rihova, Buhalis, Gouthro, \& Moital, 2018), while negative interactions lessen the perceived experience (bib_Cai_et_al_2018Cai et al., 2018bib_Cai_et_al_2018; Huang \& Wang, 2014). The interactions can be verbal and non-verbal (e.g., facial expressions and body language) (Grove \& Fisk, 1997).

In guided group activities, tourists have numerous and diverse interactions with each other (Huang \& Hsu, 2009; Kim, Byon, \& Baek, 2020). Although such interactions are a common, important, and even necessary aspect of guided group activities (Finsterwalder \& Kuppelwieser, 2011), it is surprising that they have received very little empirical research attention. A notable exception is a study of a multi-day river rafting experience that found tourist-tourist interactions contributed to "communitas", a feeling of communion with other tourists (Arnould \& Price, 1993). The interactions between the rafters resulted in shared emotional experiences and emotional attachments. Later, studies on group tourist-tourist interactions concluded that sociable incidents positively impacted satisfaction of day tours (Levy, Getz, \& Hudson, 2010) and multi-day holiday tours (Wu, 2007). This importance of tourist-tourist interaction in groups motivates our use of rapport.

\subsection{From customer-employee rapport to tourist-tourist rapport}

Rapport is the extent to which a person gets along with another person or other persons. In services research, rapport was mainly used to examine dyadic customer-employee relationships in non-group services. Gremler and Gwinner (2000, p. 92) defined customer-employee rapport as "a customer's perception of having an enjoyable interaction with a service provider employee, characterized by a personal connection between the two interactants." This notion of customer-employee rapport impacts service quality in banking and dental services (Gremler \& Gwinner, 2000) and restaurants (Kim \& Ok, 2010), and enhances service recovery in fast food, oil change, and haircutting services (DeWitt \& Brady, 2003).

Research in non-group contexts such as restaurants and hotels found that customer-employee rapport increases customers' emotional attachment to a luxury restaurant (Hyun \& Kim, 2014) and mediates customer orientation in restaurant employees with service outcomes (Kim \& Ok, 2010). Likewise, for hotel check-ins, employee eye contact and courtesy build customer-employee rapport, and subsequently customer satisfaction (Kim \& Baker, 2019), while restaurant servicescapes influence interactions and resulting customer-employee rapport (Kaminakis, Karantinou, Koritos, \& Gounaris, 2019). Given these findings, we suggest that rapport among tourists is also important, especially in group contexts. However, we found only two studies that examined tourist-tourist rapport in groups. Hwang and Lee (2019) found that rapport in multi-day holiday tours impacted tourists' perception of quality, satisfaction, and word-of-mouth. Chang, Tsaur, Yen, and Lai (2020) and found that the fit among members on a group tour positively related to rapport and satisfaction. Although both studies used a group context, they relied on dyadic dimensions of rapport developed for customer-employee relationships (Gremler \& Gwinner, 2000). We now make the case that the group context necessitates both dyadic and group-based dimensions of rapport.

\subsection{Dyadic and group-based dimensions of rapport}

Gremler and Gwinner (2000) characterized customer-employee rapport in retail services using two dimensions: enjoyable interaction (i.e., a customer's assessment of the exchanges with a service employee) and personal connection (i.e., a customer's view of the personal bond or affiliation with a service employee). While these two dyadic dimensions of customer-employee rapport can be used for tourists in guided group activities, the literature suggests that rapport in groups will likely be more complex for two reasons. First, tourist-tourist rapport will typically be influenced by group members' attentiveness to other members. This is consistent with the mutual attentiveness conceptualization of rapport proposed by Tickle-Degnen and Rosenthal (1990), described as group-directed mutual interest through focused involvement. Bernieri, Gillis, Davis, and Grahe (1996) propose that behaviors such as head nods, "um-hmms", eye contact, and physical proximity indicate when others in a group are interested in what one is doing and saying. Such behaviors equate to group member civility where members respect others' needs and feelings (Macintosh, 2009). In other words, empathic 
listening and concentration towards others in the group result in mutual attentiveness as a group-based dimension of rapport.

Second, tourist-tourist rapport in a group will be influenced by whether the tourists share similar views about the activity. When group members are mutually (un)happy about a guided group activity, they will share a feeling of balance and harmony (Tickle-Degnen \& Rosenthal, 1990) and joint psychological similarity (Duck, 1994). This aspect of group-based rapport is consistent with "experience congruity", the similarity of a focal customer's views with other customers' views about a service (Wu, Mattila, Wang, \& Hanks, 2016) and "value congruity", the similarity of an individual's values with those of others (Islam, Rahman, \& Hollebeek, 2018). Similarity-attraction theory suggests that such congruity leads to a preference for people to have relationships with those who share similar views (Byrne, Griffitt, \& Stefaniak, 1967). Further, drawing on social identity theory (Tajfel, 1981) and the principle of congruity (Osgood \& Tannenbaum, 1955), Nguyen, Ferraro, and Sands (2020) found that congruity in customer characteristics positively affects focal customer outcomes. All this suggests that congruity with fellow tourists in how they experience a group activity will affect rapport.

In sum, the literature suggests that dyadic dimensions of customeremployee rapport - personal connection and enjoyable interaction should be adapted for tourist-tourist rapport. For group contexts, the characteristics of attentiveness and congruity among group members impact their dyadic interactions and the resulting rapport. We now aim to find evidence for these dyadic and group-based dimensions of touristtourist rapport, and their impact on satisfaction with guided group activities.

\section{Methodology}

Our sequential mixed-method approach (Creswell, Klassen, Plano Clark, \& Smith, 2011; Molina-Azorín, Tarí, Pereira-Moliner, Lopez-Gamero, \& Pertusa-Ortega, 2015 ) began with a qualitative study (Study 1) to reveal dyadic and group-based dimensions of rapport, identify items for these dimensions, and develop hypotheses (see Table 1). Study 2 used a video experiment and an Amazon Mechanical Turk sample to test the dimensions. This type of experiment offers precise control of extraneous and independent variables, allowing cause and effect relationships to be established. However, the media artificiality of the video limits the extent to which respondents can fully experience the depicted group activity. Study 3 used a field experiment of real food tours and a tourist sample to validate the dimensions. This study allowed participants to experience an actual group activity versus the highly controlled

Table 1

Research overview.

\begin{tabular}{|c|c|c|c|}
\hline & Study 1 & Study 2 & Study 3 \\
\hline Purpose & $\begin{array}{l}\text { Adapt recognized } \\
\text { dyadic dimensions } \\
\text { and derive new } \\
\text { group-based } \\
\text { dimensions. Identify } \\
\text { dimension items, } \\
\text { hypotheses and } \\
\text { model. }\end{array}$ & $\begin{array}{l}\text { Test dimensions } \\
\text { and model in } \\
\text { controlled } \\
\text { conditions with } \\
\text { high internal } \\
\text { validity }\end{array}$ & $\begin{array}{l}\text { Validate } \\
\text { dimensions and } \\
\text { model in high } \\
\text { ecological validity } \\
\text { conditions }\end{array}$ \\
\hline Method & $\begin{array}{l}\text { Semi-structured } \\
\text { interviews and } \\
\text { critical incident } \\
\text { technique }\end{array}$ & $\begin{array}{l}\text { Video experiment } \\
\text { and survey }\end{array}$ & $\begin{array}{l}\text { Field experiment } \\
\text { and survey }\end{array}$ \\
\hline Respondents & $\begin{array}{l}\text { Managers, tourists, } \\
\text { and guides }\end{array}$ & MTurk, 25+ & Tourists, $25+$ \\
\hline Sample size & $\begin{array}{l}8 \text { managers, } 12 \\
\text { tourists, } 10 \text { guides }\end{array}$ & 594 & 79 \\
\hline
\end{tabular}

video experiment. Combining the video experiment with its high internal validity, and the field experiment with its high external and ecological validity (i.e., findings likely to be generalized to actual guided group activities), counters their respective disadvantages (Viglia and Dolnicar, 2020). This mixed-method approach better allowed us to develop, test, and understand a new characterization of the rapport construct than a single method alone.

\subsection{Study 1: conceptualizing tourist-tourist rapport in guided group activities}

\subsubsection{Method}

Our literature review suggested that tourist-tourist rapport in a group context is more nuanced and multidimensional than rapport in a customer-employee context. Building on these insights, Study 1 has four aims. First, confirm and adapt recognized dyadic dimensions of touristtourist rapport. Second, derive new group-based dimensions of touristtourist rapport. Third, identify potential items to measure and test each dimension in Studies 2 and 3. And, fourth, develop the research model and hypotheses.

For Study 1, we conducted 30 interviews with three types of stakeholder involved in guided group activities: eight managers, twelve tourists, and ten guides (see Table A). They represented various types of guided group activities, based on the west coast of North America. The interviews were 45-90 min long, audio recorded, and transcribed. Following Dabholkar, Shepherd, and Thorpe (2000), we sought to link, build, and integrate the findings from each subsequent set of interviews to identify tourist-tourist interactions and related dimensions of tourist-tourist rapport in group contexts. Due to the differences in roles, we used semi-structured interviews with managers and the critical incident technique (CIT) with tourists and managers (Bitner, Booms, \& Tetreault, 1990). Data collection was stopped after theoretical saturation was reached, and no new insights were emerging.

In the interviews with managers (see Table A), we asked them to describe how the tourism firm designed tourist-tourist interactions and specific events that illustrated how tourists behaved toward each other in their guided group activity. All authors repeated careful readings of the interviews and independently identified each event as the unit of analysis, including phrases and sentences. From the agreed units of analysis, each author organized them into themes. Following the techniques proposed by Ryan and Bernard (2003), the themes used both an $a$ priori approach (based on our review of the rapport literature) to identify recognized dyadic dimensions of customer-employee rapport and an $a$ posteriori approach (based on the data) to identify potential group-based dimensions of tourist-tourist rapport.

Next, we interviewed the tourists and guides using the critical incident technique (CIT) (Bitner et al., 1990), asking each respondent to describe critical incidents among tourists that they viewed as very (dis) satisfactory. Two authors independently conducted a content analysis of the critical incidents, following Neuendorf (2017), by making repeated careful readings of all incidents, then independently coding the incidents into eight sub-themes which were then grouped into four general themes corresponding to the four dimensions of tourist-tourist rapport. Following similar processes in tourism research (e.g., So, Oh, \& Min, 2018), we assessed how these themes and sub-themes matched the dimensions of tourist-tourist rapport derived from the interviews with managers. The third author verified each categorization, and another independent rater with professional experience in delivering guided group activities did a final verification.

\subsubsection{Results}

We identified four dimensions of tourist-tourist rapport from our interviews with managers, tourists, and guides. Two are dyadic dimensions, Enjoyable Interaction and Personal Connection, consistent with and adapted from customer-employee rapport dimensions (Gremler \& Gwinner, 2000). And two are new group-based dimensions, Service 
Table 2

Managers' view of dimensions of tourist-tourist rapport in guided group activities.

\begin{tabular}{|c|c|c|c|}
\hline & & \multicolumn{2}{|l|}{ Examples } \\
\hline \multicolumn{2}{|c|}{ Dimensions of tourist-tourist rapport } & Satisfactory & Dissatisfactory \\
\hline \multirow[t]{2}{*}{ Dyadic } & $\begin{array}{l}\text { Enjoyable interaction: the extent to which a focal } \\
\text { tourist perceives having pleasant exchanges with } \\
\text { another tourist }\end{array}$ & $\begin{array}{l}\text { "... the joy that appears to be present in the } \\
\text { conversations ... [individuals] feel free and open to talk } \\
\text { to one another ...." (F5, good conversation) } \\
\text { "If [individuals] aren't enjoying themselves ... } \\
\text { interacting and having a fun shared experience, then we } \\
\text { haven't done our jobs properly." (F4, fun with others) }\end{array}$ & $\begin{array}{l}\text { "You can just tell if someone is getting either frustrated } \\
\text { or ... eye-rolling,that kind of thing. Body language .... } \\
\text { You can just feel it." (F4, frustrated) } \\
\text { "If someone is just sitting in the corner, quiet, waiting } \\
\text { for things to start. It's a different atmosphere. It's a } \\
\text { tenser atmosphere." (F7, uncomfortable) }\end{array}$ \\
\hline & $\begin{array}{l}\text { Personal connection: the extent to which a focal } \\
\text { tourist perceives having a bond with another tourist }\end{array}$ & $\begin{array}{l}\text { "It's super common at the end of a meal to see people } \\
\text { exchanging phone numbers and email addresses and } \\
\text { what wine area are you going to tomorrow or what else } \\
\text { are you doing while you're here." (F5, developing } \\
\text { friendships) } \\
\text { "... meet a great couple [at the event] ... you meet [again } \\
\text { [ in another couple of years" (F1, developing } \\
\text { friendships) }\end{array}$ & $\begin{array}{l}\text { "... if you get an introvert in a tour, then you're not } \\
\text { going to go anywhere with them." (F3, no connection) } \\
\text { "... one meal where there was enough dead fish [a few } \\
\text { unresponsive people] around that nobody was having } \\
\text { fun...[who] sit at the end of the table and not talk all } \\
\text { that much." (F5, no connection) }\end{array}$ \\
\hline \multirow[t]{2}{*}{$\begin{array}{l}\text { Group- } \\
\text { based }\end{array}$} & $\begin{array}{l}\text { Service congruity: the extent to which focal tourists } \\
\text { feel they share the same evaluation as other tourists } \\
\text { in the group about the guided group activity they are } \\
\text { consuming }\end{array}$ & $\begin{array}{l}\text { "When people are enthusiastic about something, that } \\
\text { will spread .... Tourists who keep thinking and saying } \\
\text { this is wonderful. ... help others catch on and also feel } \\
\text { that, it's like rings in the water." (F1, shared liking) } \\
\text { "... if everyone gets on the same page right away, then it } \\
\text { makes for a far more enjoyable class." (F8, shared } \\
\text { understanding) }\end{array}$ & $\begin{array}{l}\text { "Some of them sat and played video games the entire } \\
\text { gourmet kayaking trip, ... It actually had a negative } \\
\text { impact on all of the people ...." (F2, disinterested in } \\
\text { service) } \\
\text { "Other people standing next to them are enjoying their } \\
\text { wines. And then they'll express their dislike of it. This } \\
\text { creates doubt that spreads and ruins the ... experience } \\
\text { for everyone else, too." (F3, dislike service) }\end{array}$ \\
\hline & $\begin{array}{l}\text { Group attentiveness: the extent to which focal } \\
\text { tourists feel that other tourists in the group show } \\
\text { consideration and interest toward each other }\end{array}$ & $\begin{array}{l}\text { "We'll get everyone ... in a circle. And then [they will] } \\
\ldots \text { introduce yourself and a little bit about yourself. So } \\
\text { you get them used to the idea of talking in the group ... } \\
\text { then we'll do exercises that will force them to interact } \\
\text { with everybody off the top as well." (F8, organized } \\
\text { communication) } \\
\text { "We make the first course a sharing course ... because it } \\
\text { forces people to interact a little bit. They're just asking } \\
\text { somebody to pass something or 'are you going to eat } \\
\text { that?' Just the kind of conversation that happens at a } \\
\text { table." (F5, organic communication) }\end{array}$ & $\begin{array}{l}\text { "We've had people that talk a lot and just don't stop } \\
\text { talking." (F4, inattentive to others) } \\
\text { "They'll wander off and do their own thing or they'll } \\
\text { stop and take pictures of something." (F3, inattentive to } \\
\text { others) }\end{array}$ \\
\hline
\end{tabular}

Table 3

Tourists' and guides' views of incidents of tourist-tourist rapport.

\begin{tabular}{|c|c|c|c|c|c|}
\hline & \multirow[b]{2}{*}{ No. incidents } & \multicolumn{2}{|l|}{ Tourists } & \multicolumn{2}{|l|}{ Guides } \\
\hline & & Very satisfactory & Very dissatisfactory & Very satisfactory & Very dissatisfactory \\
\hline Service congruity & 19 & 3 & 4 & 7 & 5 \\
\hline (No) Shared liking of group activity & 9 & 2 & 2 & 4 & 1 \\
\hline (No) Shared understanding of group activity & 10 & 1 & 2 & 3 & 4 \\
\hline Very satisfactory (guide) & \multirow{2}{*}{\multicolumn{5}{|c|}{$\begin{array}{l}\text { “... a mother moose was crossing ... the highway and someone spotted it ... had gotten out of the water but the baby was having difficulty. The } \\
\text { mother went back into the water, went behind the little one, and pushed it out ... it made everyone's day." } \\
\text { "[During] a funny show ... a woman in the audience ... just yelled out 'Hey, I'm an American, and you shouldn't be making fun of him, you } \\
\text { should be making fun of her.' And the whole audience just went completely quiet." }\end{array}$}} \\
\hline Very dissatisfactory (tourist) & & & & & \\
\hline Group attentiveness & 27 & 15 & 2 & 9 & 1 \\
\hline (No) Interest in others & 18 & 10 & 1 & 6 & 1 \\
\hline (Un)Helpfulness & 9 & 5 & 1 & 3 & 0 \\
\hline Very satisfactory (tourist) & \multirow{2}{*}{\multicolumn{5}{|c|}{$\begin{array}{l}\text { "... we ... had a good } 20-25 \mathrm{~min} . . . \text { for everyone to introduce themselves and say where they're from and that kind of broke the ice a little bit. } \\
\text { [The] opportunity to kind of sit and take a moment to introduce ourselves was helpful to kind of break the ice. } \\
\text { "There probably were about } 12 \text { people on the tour, including my wife and I and we did not know anybody else on the tour .... They were nice } \\
\text { people, but they were ... having a party among themselves .... So, we felt a little left out." }\end{array}$}} \\
\hline Very dissatisfactory (tourist) & & & & & \\
\hline Enjoyable interaction & 18 & 9 & 1 & 4 & 4 \\
\hline (Un)Comfortable with others & 9 & 3 & 1 & 2 & 3 \\
\hline (Dis)Liking other tourists & 9 & 6 & 0 & 2 & 1 \\
\hline Very satisfactory (tourist) & \multicolumn{5}{|c|}{$\begin{array}{l}\text { "... we were on a food tour in Austin and we had a nice time because we were talking to other people on the tour and getting to know them and } \\
\text { making observations about the various foods that we were trying - and that had a very positive impact." }\end{array}$} \\
\hline Very dissatisfactory (guide) & \multicolumn{5}{|c|}{ "You could feel the mood kind of change, people got kind of quiet, and people looked to me as ... what's going to happen .... " } \\
\hline Personal connection & 20 & 14 & $\boldsymbol{O}$ & 6 & $\boldsymbol{O}$ \\
\hline Something in common & 10 & 9 & 0 & 1 & 0 \\
\hline Developing friendships & 10 & 5 & 0 & 5 & 0 \\
\hline Very satisfactory (tourist) & \multicolumn{5}{|c|}{$\begin{array}{l}\text { ",.. a husband and wife ... we got along so well during the beer tour that ... we went on to have dinner together and talked away that night and ... } \\
\text { are in touch via Facebook." }\end{array}$} \\
\hline Very satisfactory (guide) & \multicolumn{5}{|c|}{$\begin{array}{l}\text { "... they form a Whatsapp group ... to keep in touch and sometimes they add me on, and so you keep in touch ... I think that rapport that you } \\
\text { build is the most positive thing that comes out of these travels because you make a friend for life." }\end{array}$} \\
\hline Column Total & 84 & 41 & 7 & 26 & 10 \\
\hline
\end{tabular}


Congruity and Group Attentiveness, suggested by the literature on group services. Table 2 summarizes the manager interviews and presents the four dimensions, including illustrative quotes. Table 3 summarizes the CIT interviews with tourists and guides that generated 84 critical incidents (67 satisfactory and 17 dissatisfactory), and shows illustrative quotes. Of the 84 critical incidents, 19 (23\%) were assigned to the Service Congruity dimension, 27 (32\%) to Group Attentiveness, 18 (21\%) to Enjoyable Interaction, and $20(24 \%)$ to Personal Connection. We now discuss each dimension.

For the context of tourist-tourist rapport in groups, we define Enjoyable Interaction as the extent to which a focal tourist perceives having pleasant exchanges with another tourist. All managers declared that Enjoyable Interaction is a common and important component of guided group activities. Enjoyable Interaction includes sub-themes of (not) liking another tourist and feeling (un)comfortable with another tourist. The narratives of liking other tourists involved pleasant conversations or fun with another tourist (versus unpleasant conversations or finding another tourist to be obnoxious). The narratives of feeling comfortable with another tourist included others being in a good mood or feeling safe with another tourist (versus tourists arguing or negative body language such as eye-rolling).

We define Personal Connection as the extent to which a focal tourist perceives having a bond with another tourist. Personal Connection includes sub-themes of having something in common (or not) and developing friendships (or not). Narratives of having something in common involved having similar backgrounds and interests (versus not finding similarities). Narratives of developing friendships included making plans to go to dinner together, deeper discussions about life, or exchanging contact information. All managers believed that the bonds and affiliations associated with Personal Connection between tourists could increase satisfaction with the guided group activity. In contrast, they all reported that satisfaction decreases when tourists feel unconnected or have little in common.

The group-based dimensions, Service Congruity and Group Attentiveness, arise from interactions among the focal tourist and the group, rather than between the focal tourist and another tourist. Managers indicated that activities are designed to facilitate interactions among the group of strangers, such as having tourists introduce themselves to the group and ice breaker games (Group Attentiveness) and sharing moments to spark conversation (Service Congruity). These group-based dimensions allow tourists to proceed to have pleasant conversations (Enjoyable Interaction) and to find something in common with each other (Personal Connection). Manager F2 explains the facilitation of the group-based dimensions as, "we would create games and ways that people can interact to force them to interact." This facilitation among the group makes it easier for tourists to talk to each other. Manager F8 reveals that the group-based interactions enable strangers to develop dyadic relationships with each other: "this group of people [where] ... no one knows anybody. And ... by the end ... [they are] making plans to go get drinks ... it's a by-product of ... everyone interacting and getting together and you just start to trust people."

We define Service Congruity as the extent to which focal tourists perceive they share the same evaluation as the group about their group activity. Service Congruity includes sub-themes of (not) shared liking and (not) shared understanding of certain aspects of the group activity (e.g., tour guide, food, setting or organization). Narratives for shared liking included tourists being enthusiastic about an animal sighting or an exhilarating river rafting experience (versus one or more unhappy tourists), while narratives for shared understanding included tourists sharing (or not) expectations of the group activity such as cycling ability on a cycling tour or culturally sensitive behavior. Congruity toward the activity is important in fostering trust between individuals (e.g., Hart, Capps, Cangemi, \& Caillouet, 1986). Service Congruity also relates to participants being on the same page about something central to the group (Tickle-Degnen \& Rosenthal, 1990).

We define Group Attentiveness as the extent to which focal tourists feel that group members show interest and consideration toward each other. That is, whether the group pays attention to what individual members are saying and doing. Group Attentiveness includes the subthemes of (dis)interest in others and (un)helpfulness (see Table 3). Narratives for interest in others included tourists introducing themselves or participating in conversations versus not participating or feeling excluded. Narratives for helpfulness included tourists providing suggestions and helping others, versus behaving selfishly. Group Attentiveness impacts a group's spatial behavior, i.e., how individuals react to others and their activities (Spoor \& Kelly, 2004). It is typically reflected by cues such as eye contact, smiling, head nodding, and leaning toward others (Bernieri et al., 1996).

\subsubsection{Model and hypotheses}

We propose a research model (Fig. 1) for the relationships between the four dimensions of tourist-tourist rapport and satisfaction with a guided group activity. Our interviews suggest that the group-based dimensions of Group Attentiveness and Service Congruity create the conditions for the dyadic dimensions of Enjoyable Interaction and Personal Connection to develop and increase satisfaction. For example, manager F4 has tourists introduce themselves or play a game, "just to get people laughing and moving". Such introductory exercises give tourists "something in common to talk about right off the bat ... then you ... find ... this person likes to run [too] ...,or, [this person is] from Prince George, you're from an hour down the road .... [allowing tourists to] find a relationship between customers." Normally, tourists in a guided group activity are asked to introduce themselves to the group "because that's what gets them going ... toward building that rapport .... They can sit and chit chat ... develop their rapport .... to form those bonds" (guide G3). These comments were consistent among the respondents. When tourists perceive other tourists as having a shared liking and understanding about the group activity (i.e., Service Congruity), and being interested and helpful to others (i.e., Group Attentiveness), this helps a focal tourist to engage with (Enjoyable Interaction) and explore commonalities (Personal Connection) with another tourist. In other words, activities that help align and unite a group of tourists could also help the tourists in the group to overcome any reluctance to engage and connect. Conversely, when a satisfied focal tourist witnesses other tourists acting bored, unhappy, or critical of the group activity (i.e., a lack of Service Congruity), or disinterested in or unhelpful to the members of the group (i.e., a lack of Group Attentiveness), this incompatibility in group-based rapport hinders the development of the dyadic dimensions of touristtourist rapport. From this reasoning, we hypothesize and investigate the relationships between the dyadic and new group-based dimensions as follows:

H1: The dyadic dimensions of tourist-tourist rapport (enjoyable interaction and personal connection) mediate the relationship between the group-based dimensions of tourist-tourist rapport (service congruity and group attentiveness) and satisfaction with the guided group activity.

\section{Figure 1. Hypothesized research model}

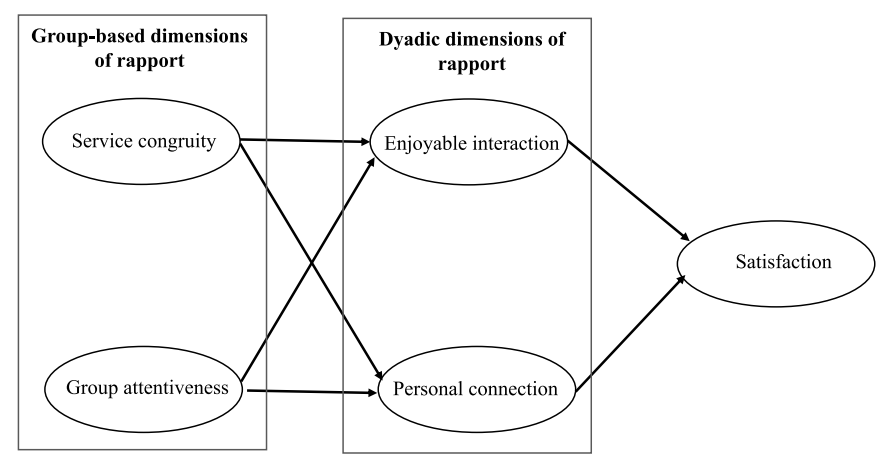

Fig. 1. Hypothesized research model. 
Study 1 also indicates that a focal tourist is more satisfied when that tourist has an opportunity to develop rapport with other tourists. For example, tourist T1 explained her satisfaction with a food tour, "had we not felt so comfortable in the group, maybe we wouldn't have had such a positive experience ... but because ... [the guide] made it so relaxed from the very beginning, really trying to get everybody involved ... that just helped alleviate any stress." Tourist T10 discussed having rapport with other tourists: "it was an organized walking tour ... with couples and individuals .... It was very, very enjoyable, and I got to meet lots of interesting people .... to have a guide and to have other people around to ... talk [to] as you go along made the holiday complete ... for me ... that's part of the fun ... in the week following we exchanged photographs and emails and all that sort of thing .... [there was] chemistry between the individuals." Conversely, a lack of rapport makes a focal tourist more dissatisfied with the guided group activity. Tourist T11 explained the impact of a disruptive group member, "it did kind of put me on edge and uncomfortable after that, thinking is she going to say something else?.. I've definitely talked about it since and told the story a number of times because ... it was so unbelievable." From these insights, we hypothesize:

H2: Tourist-tourist rapport is positively related to satisfaction with the guided group activity.

\subsection{Study 2: video experiment}

Based on the four dimensions of tourist-tourist rapport derived from Study 1 , we next examined the relationships between these four dimensions (H1) and how different levels of tourist-tourist rapport impact satisfaction of a guided group service (H2). We used a video experiment where we produced videos of three different tourist-tourist rapport conditions (high, moderate, and low rapport) in the context of a group food tour. The moderate condition was a control group, where tourists exhibited normal levels of rapport, as would be expected during a group tour with strangers. The high and low rapport conditions showed the tourists having higher and lower levels of rapport, respectively. Participants viewed one of the three videos and answered questions about the perceived rapport among tourists.

\subsubsection{Method}

Video experiment design. Experiments are increasingly common and useful in services and marketing research (e.g., Luong, 2005; Victorino, Verma, Border, \& Wardell, 2012). Given this method's ability to test causal relationships and isolate and manipulate interventions, there have been calls to use experiments more in tourism research (Hwang \& Mattila, 2018; Viglia \& Dolnicar, 2020). We chose a video experiment for three reasons. First, it allowed us complete control of the environment, such as the tour guide, the setting, and the other tourists. This control enabled us to isolate the independent variable (tourist-tourist rapport) while reducing potential confounds (Szymanski \& Henard, 2001 ) to achieve high internal validity (Viglia \& Dolnicar, 2020). Second, video scenarios can consistently convey the range of behaviors that depict the four dimensions, including verbal, non-verbal, and intangible behaviors (Victorino \& Dixon, 2016). This helps the experiment achieve high realism and reduce the artificiality of other types of laboratory experiments (Viglia \& Dolnicar, 2020). Third, compared to written scenarios, videos are less susceptible to error variances, such as participants imagining behaviors not provided in the scenario and inaccurate interpretations of words (Seawright \& Sampson, 2007).

The three video scenarios, depicting high, moderate, and low levels of tourist-tourist rapport, show approximately $7 \mathrm{~min}$ of an actual food tour. We worked with a food tour firm to develop realistic videos. Each of the three video scenarios included trained actors portraying six tourists and a tour guide. Table $\mathrm{B}$ outlines the video preparation and pretesting, the video scenarios, and key high, moderate, and low-rapport conditions.

Data collection. Research participants were from Amazon Mechanical
Turk (MTurk). MTurk has been used in studies of tourist engagement on social media (Harrigan, Evers, Miles, \& Daly, 2017), hotel brand relationships with consumers (Casidy, Wymer, \& O'Cass, 2018), and burnout of restaurant employees (Kim \& Qu, 2019). In our video experiment, participants were randomly assigned to one of the rapport conditions, asked to identify with a specific character in the video, and complete an online survey. MTurk's online participant pool was chosen for several reasons. It has a large and diverse participant pool of adults in the U.S. It allows research participants to be pre-screened for characteristics such as demographics. It delivers high-quality data and offers more diversity than convenience samples (Buhrmester, Kwang, \& Gosling, 2011; Eggert, Steinhoff, \& Garnefeld, 2015). Data collection is fast, fewer than $24 \mathrm{~h}$, limiting participants' ability to inform other participants of the study's purpose (bib_Aguinis_et_al_2020Aguinis, Villamor, \& Ramani, 2020bib_Aguinis_et_al_2020).

We only accepted responses from U.S. MTurk users who were $25+$ of age to help ensure participants were representative of the general adult U.S. population (Ross, Irani, Silberman, Zaldivar, \& Tomlinson, 2010, pp. 2863-2872) and similar in age to tourists participating in group activities like those in Study 1. Participants had previous experience in paid group activities. To ensure participants watched the entire video and filled in the online survey attentively and accurately, we included four attention checks and ensured that participants could not skip the video. The sample comprised 594 responses ( $82 \%$ of 721 ) after eliminating incomplete or ineligible responses. Participants were randomly assigned, with responses spread evenly across the rapport conditions: 202 high, 203 moderate, and 189 low. The sample was 52\% female, had an average age of 37 , and $57 \%$ had at least a bachelor's degree, with no significant differences between participants for each condition. The questions were pretested, as detailed in Table B.

Measures and measurement validation. This experiment comprised a one-factor between-subjects design, and the independent variable was the level of tourist-tourist rapport: (i) high, (ii) moderate, and (iii) low. The questions that measured the dimensions of tourist-tourist rapport were derived from the findings of Study 1 and previous literature.

The group-based dimensions Service Congruity (SC) and Group Attentiveness (GA) were measured through items SC1 to SC4 and GA1 to GA5, respectively (see Table C). As Service Congruity and Group Attentiveness are both new dimensions, the items for each were generated from the findings in Study 1, specifically from the sub-themes for each dimension (see Table 3), and corroborated with relevant literature (see Table C). The four SC items measured the perception of the other tourists' enthusiasm (disinterest) and (dis)liking of the group activity. Since all respondents evaluated the same group tour, designed to be of good quality, negative valenced items were not expected to be strongly negative. The GA items measured the perception of the other tourists' (dis)interest in talking to me (the respondent), (dis)interest in talking to each other, and being helpful.

The dyadic dimensions Enjoyable Interaction (EI) and Personal Connection (PC) were measured through items EI1 to EI8 and PC1 to PC4, respectively. While both these dimensions were conceptualized for customer-employee rapport in a non-group context (Gremler \& Gwinner, 2000), additional items were generated from Study 1 for a group context. Two of the EI items about feeling (un)comfortable with other tourists were adapted from Gremler and Gwinner (2000). The other six EI items measured (dis)liking of the other tourists, being glad to be with the other tourists (would have preferred to take the tour by myself), and perception of other tourists being (im)polite. Two of the PC items about friendships were adapted from Gremler and Gwinner (2000), while the other two items were about having (not having) something personal in common. The dependent variable Satisfaction measured service outcomes and comprised five items SAT1 to SAT5. The items measured the quality of the overall experience, satisfaction with the overall experience, how the overall experience met expectations, intention to recommend, and loyalty (Gremler \& Gwinner, 2000; Mattila, Grandey, \& Fisk, 2003). 
Exploratory factor analysis (EFA). To verify the discriminant validity of our measurement model, we conducted an EFA with a principal components analysis and direct oblimin rotation. The EFA revealed our five-factor model and the items loaded on their respective factors, as expected. Items were accepted if (a) the loading on a factor was 0.50 or greater, (b) the loading on other factors was less than 0.40 , and (c) the cross-loading differential between factors was greater than 0.20 . We retained two items for Service Congruity, four for Group Attentiveness, three for Enjoyable Interaction, four for Personal Connection, and five for
Satisfaction (Table 4). Retained items had high internal consistency, with Cronbach's $\alpha$ at 0.85 or higher for each factor (Nunnally, 1978).

\subsubsection{Analysis and results}

Measurement model results. We then conducted a confirmatory factor analysis (CFA) using AMOS 24 to test for convergent and discriminant validity. The measurement model statistics (Table 4) and the overall fit statistics indicate that the five-factor model fits the data well (RMSEA = $\left.0.062, C F I=0.976, T L I=0.968, S R M R=0.032, \chi^{2}{ }_{594}=382.8\right)$ and

Table 4

Study 2 measurement model results.

\begin{tabular}{|c|c|c|c|c|c|c|c|}
\hline & \multicolumn{7}{|c|}{ Overall Model Fit } \\
\hline & $\chi^{2}$ & $f$ & $p$ & RMSEA & CFI & $T L I$ & SRMR \\
\hline & 382.8 & 0 & 0.000 & 0.062 & 0.976 & 0.968 & 0.032 \\
\hline \multirow[t]{3}{*}{ Construct and Scale Items } & \multicolumn{2}{|l|}{ EFA } & \multicolumn{5}{|c|}{ Internal Consistency } \\
\hline & Factor & & Standardized & Composite & Cron- & Average Variance & Maximum Shared \\
\hline & Loading & & Loading & Reliability & bach's $\alpha$ & Extracted & Variance \\
\hline Service Congruity & & & & 0.859 & 0.85 & 0.753 & 0.717 \\
\hline $\begin{array}{l}\text { I sensed enthusiasm from other customers about the } \\
\text { tour }\end{array}$ & 0.669 & & 0.887 & & & & \\
\hline I felt other customers liked the tour & 0.769 & & 0.848 & & & & \\
\hline $\begin{array}{l}\text { I sensed disinterest from other customers about the } \\
\text { tour* }\end{array}$ & 0.755 & & - & & & & \\
\hline I felt other customers disliked the tour* & 0.803 & & - & & & & \\
\hline Group Attentiveness & & & & 0.927 & 0.91 & 0.761 & 0.745 \\
\hline $\begin{array}{l}\text { I felt other customers on the tour were interested in } \\
\text { talking to me }\end{array}$ & 0.740 & & 0.829 & & & & \\
\hline $\begin{array}{l}\text { I felt other customers on the tour were not interested } \\
\text { in talking to me* }\end{array}$ & 0.572 & & 0.911 & & & & \\
\hline $\begin{array}{l}\text { I felt other customers on the tour were not interested } \\
\text { in talking to each other* }\end{array}$ & 0.720 & & 0.827 & & & & \\
\hline $\begin{array}{l}\text { On the whole, I felt other customers on the tour were } \\
\text { helpful }\end{array}$ & 0.554 & & 0.919 & & & & \\
\hline $\begin{array}{l}\text { I felt other customers on the tour were interested in } \\
\text { talking to each other }\end{array}$ & 0.834 & & - & & & & \\
\hline Enjoyable Interaction & & & & 0.900 & 0.90 & 0.751 & 0.745 \\
\hline I liked other customers on the tour. & 0.543 & & 0.907 & & & & \\
\hline I felt comfortable with other customers on the tour & 0.641 & & 0.864 & & & & \\
\hline I felt other customers on the tour were polite & 0.522 & & 0.827 & & & & \\
\hline $\begin{array}{l}\text { I felt uncomfortable with other customers on the } \\
\text { tour* }\end{array}$ & 0.640 & & - & & & & \\
\hline $\begin{array}{l}\text { I'm glad I took this tour in the company of other } \\
\text { customers }\end{array}$ & 0.653 & & - & & & & \\
\hline $\begin{array}{l}\text { I would have preferred to have taken the tour by } \\
\text { myself without other customers* }\end{array}$ & 0.781 & & - & & & & \\
\hline I disliked other customers on the tour* & 0.651 & & - & & & & \\
\hline I felt other customers on the tour were rude* & 0.562 & & - & & & & \\
\hline Personal Connection & & & & 0.925 & 0.93 & 0.757 & 0.579 \\
\hline $\begin{array}{l}\text { I felt friendships were developed with some } \\
\text { customers on the tour }\end{array}$ & 0.716 & & 0.919 & & & & \\
\hline $\begin{array}{l}\text { I felt friendships were not developed with any } \\
\text { customers on the tour* }\end{array}$ & 0.744 & & 0.950 & & & & \\
\hline $\begin{array}{l}\text { I felt some customers on the tour had something } \\
\text { personal in common }\end{array}$ & 0.812 & & 0.803 & & & & \\
\hline $\begin{array}{l}\text { I felt customers on the tour did not have anything } \\
\text { personal in common* }\end{array}$ & 0.876 & & 0.797 & & & & \\
\hline Satisfaction & & & & 0.954 & 0.95 & 0.808 & 0.557 \\
\hline The quality of the overall experience by $\ldots$ is & 0.856 & & 0.908 & & & & \\
\hline $\begin{array}{l}\text { My feelings toward the overall experience by ... can } \\
\text { best be described as }\end{array}$ & 0.828 & & 0.963 & & & & \\
\hline Would you recommend ... to your friends and family? & 0.962 & & 0.856 & & & & \\
\hline $\begin{array}{l}\text { How likely is it that you would take another tour with } \\
\text {...? }\end{array}$ & 0.891 & & 0.830 & & & & \\
\hline The overall experience by $\ldots$ is & 0.678 & & 0.930 & & & & \\
\hline
\end{tabular}

Notes: * reverse coded.

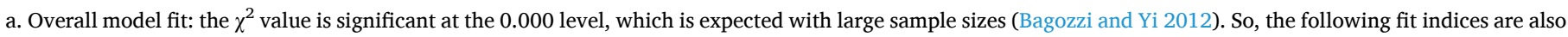

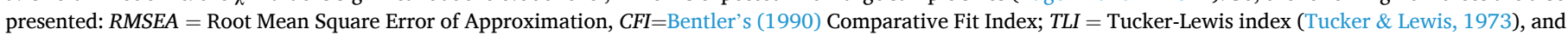
$S R M R=$ Standardized Root Mean Residual.

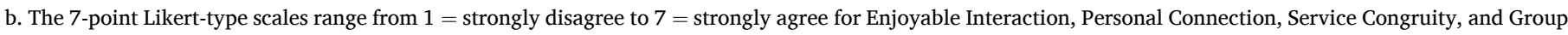

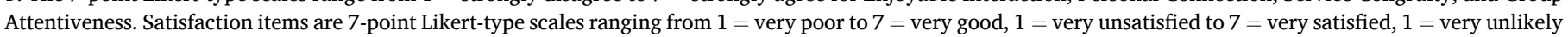
to $7=$ very likely, and $1=$ much worse than expected to $7=$ much better than expected for respective questions.

c. All indicator loadings for the measurement model are significant $(p<0.001)$. 
Table 5

Study 2 correlations among latent factors.

\begin{tabular}{|c|c|c|c|c|c|}
\hline & Personal Connection & Enjoyable Interaction & Satisfaction & Group Attentiveness & Service Congruity \\
\hline Personal Connection & $0.870^{\mathrm{a}}$ & & & & \\
\hline Enjoyable Interaction & 0.754 & $0.867^{\mathrm{a}}$ & & & \\
\hline Satisfaction & 0.702 & 0.746 & $0.899^{\mathrm{a}}$ & & \\
\hline Group Attentiveness & 0.761 & 0.863 & 0.626 & $0.873^{\mathrm{a}}$ & \\
\hline Service Congruity & 0.689 & 0.847 & 0.738 & 0.771 & $0.868^{\mathrm{a}}$ \\
\hline
\end{tabular}

a The square root of $A V E$ for each factor is in the diagonal. The square root of $A V E$ is greater than the inter-construct correlations.

exceeds the standards proposed by Hu and Bentler (1998; 1999). All factors demonstrate high composite reliability, with values for each factor exceeding 0.85 , well above the recommended value of 0.70 (Nunnally, 1978). All values of average variance extracted (AVE) were greater than 0.7, exceeding the recommended value of 0.5 (Bagozzi \& Yi, 1988), thus demonstrating convergent validity (Fornell \& Larcker, 1981). Table 5 shows that $A V E$ values for all factors were greater than maximum shared variance (MSV) and the square root of the $A V E$ values for all factors was greater than the inter-construct correlations, demonstrating discriminant validity (Fornell \& Larcker, 1981). Thus, the measurement model exhibits a high level of convergent and discriminant validity.

Structural model results. To assess H1, structural equation modeling was used to determine the relationship between the four dimensions of rapport. The goodness-of-fit indices (see Table 6) suggest a good fit of the hypothesized model (see Fig. 2) to the data in Study 2 $(R M S E A=0.067, C F I=0.970, T L I=0.961, S R M R=0.038$, $\chi^{2}{ }_{594}=480.1$ ). All the standardized path coefficients between the four rapport variables and Satisfaction are positive and significant. The amount of variance explained, measured in terms of $R^{2}$, is 0.839 for Enjoyable Interaction which is considered substantial, 0.746 for Personal Connection, also considered substantial; and 0.601 for Satisfaction, considered moderate to substantial (Hair, Celsi, Ortinau, \& Bush, 2010).

Table 6

Study 2 structural model results.

\begin{tabular}{|c|c|c|}
\hline & \multicolumn{2}{|l|}{ Overall Model Fit } \\
\hline \multicolumn{3}{|l|}{ Structural Model Statistic } \\
\hline$\chi^{2}$ & \multicolumn{2}{|l|}{480.1} \\
\hline$D f$ & \multicolumn{2}{|l|}{130} \\
\hline$P$ & \multicolumn{2}{|l|}{0.000} \\
\hline RMSEA & \multicolumn{2}{|l|}{0.067} \\
\hline CFI & \multicolumn{2}{|l|}{0.970} \\
\hline$T L I$ & \multicolumn{2}{|l|}{0.961} \\
\hline SRMR & \multicolumn{2}{|l|}{0.038} \\
\hline Path & \multicolumn{2}{|l|}{ Estimate } \\
\hline Attentiveness $\rightarrow$ Enjoyable Interaction & 0.455 & 9.488 \\
\hline Attentiveness $\rightarrow$ Personal Connection & 0.348 & 7.56 \\
\hline $\begin{array}{l}\text { Service Congruity } \rightarrow \text { Enjoyable } \\
\text { Interaction }\end{array}$ & 0.588 & 9.555 \\
\hline $\begin{array}{l}\text { Service Congruity } \rightarrow \text { Personal } \\
\text { Connection }\end{array}$ & 0.186 & 3.311 \\
\hline Enjoyable Interaction $\rightarrow$ Satisfaction & 0.446 & 10.349 \\
\hline \multirow[t]{2}{*}{ Personal Connection $\rightarrow$ Satisfaction } & 0.34 & 6.635 \\
\hline & \multicolumn{2}{|c|}{$\begin{array}{l}\text { Variance Explained for Endogenous } \\
\text { Variables }\end{array}$} \\
\hline$R^{2}$ - Enjoyable Interaction & \multicolumn{2}{|l|}{0.839} \\
\hline$R^{2}-$ Personal Connection & \multicolumn{2}{|l|}{0.746} \\
\hline$R^{2}$ - Satisfaction & \multicolumn{2}{|l|}{0.601} \\
\hline
\end{tabular}

Notes: The $\chi^{2}$ statistic is significant at the 0.000 level, as expected with large sample sizes (Bagozzi and Yi, 2012). RMSEA = Root Mean Square Error of Approximation, CFI = Bentler's (1990) Comparative Fit Index; TLI = Tucker-Lewis index (Tucker \& Lewis, 1973), and SRMS = Standardized Root Mean Residual. $t$-values are significant at the 0.001 level.

The structural model considers the high, moderate, and low-rapport scenarios by controlling for the variable Scenario.

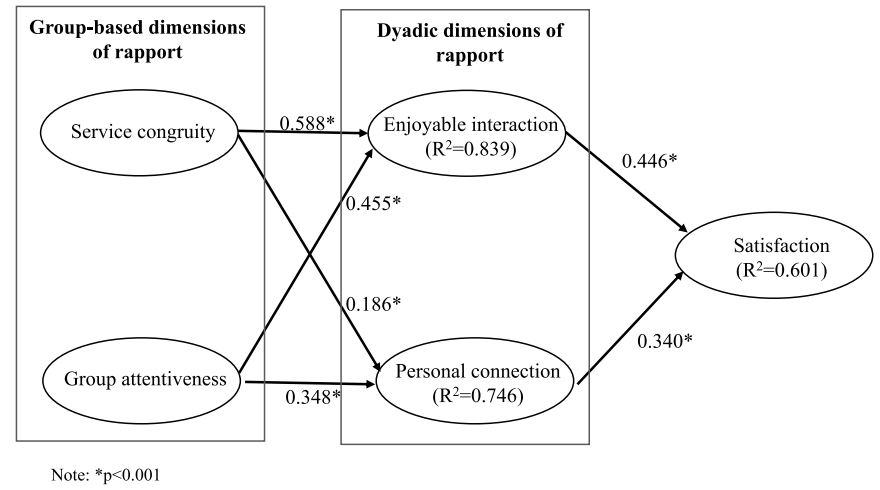

Fig. 2. Summary of structural model results.

Procedure and manipulation checks. To verify that participants could perceive the level of rapport of each scenario, we empirically validated the experimental manipulations. We asked the participants six manipulation questions, MN1 to MN3 and CF1 to CF3 (see Table C). Questions MN1 to MN3 verified whether participants could distinguish between the three scenarios, and show high internal consistency (Cronbach's $\alpha=$ 0.94). A one-tailed $t$-test showed they clearly identified the difference between the high-rapport and moderate-rapport scenarios $\left(M_{\text {high }}=6.01\right.$, $\left.S D=0.92, M_{\text {moderate }}=5.01, S D=1.25, t=9.16, p<0.001\right)$, and between the low-rapport and moderate-rapport scenarios $\left(M_{\text {low }}=2.52, S D\right.$ $\left.=1.15, M_{\text {moderate }}=5.01, S D=1.25, t=20.61, p<0.001\right)$. Further, confounding check questions CF1 to CF3 showed acceptable internal consistency (Cronbach's $\alpha=0.72$ ) (Bland \& Altman, 1997). This check assessed whether the behavior of the tour guide was perceived differently across the scenarios (Perdue \& Summers, 1986). A one-tailed $t$-test showed that participants did not perceive a significant difference in the behavior of the tour guide, neither between the high-rapport and moderate-rapport scenarios $\left(M_{\text {high }}=6.27, S D=0.76, M_{\text {moderate }}=6.22\right.$, $S D=0.79, t=0.59, p=0.555)$ nor between the low-rapport and moderate-rapport scenarios $\left(M_{\text {low }}=6.32, S D=0.74, M_{\text {moderate }}=6.22\right.$, $S D=0.79, t=1.28, p=0.201$ ).

We performed a manipulation check to test for any difference between expectations and perceptions of other tourists' behavior, following expectancy confirmation theory (e.g., Oliver, 1980). Participants answered a question about their expectation of other tourists' behavior before viewing the video, and a similar question after viewing it (see Table C). As expected, a paired $t$-test indicated a significant difference between expectation and perception for the high-rapport $(t=$ $5.85, p<0.001)$ and low-rapport $(t=22.27, p<0.001)$ videos, as shown in Table 7. There was also a significant difference between expectation and perception for the moderate-rapport video $(t=6.02, p<0.001)$, indicating that participants expected higher rapport than they perceived in the video $\left(\mathrm{M}_{\text {expectation }}=5.59, \mathrm{M}_{\text {perception }}=4.93\right)$.

Assessment of levels of rapport on satisfaction. To assess H2, we performed two sets of one-tailed t-tests on the four dimensions of rapport and satisfaction. Since the moderate-rapport scenario was designed to be a control group, the first set of t-tests was between the high-rapport and moderate-rapport video scenarios. The second set was between the low- 
Table 7

Study 2 and 3 paired one-tailed $t$-test: expectation vs. perception of other tourists.

\begin{tabular}{|c|c|c|c|c|c|}
\hline \multirow[t]{2}{*}{ Scenario } & \multirow{2}{*}{$\begin{array}{l}\text { Test } \\
\text { statistic }\end{array}$} & \multirow{2}{*}{$\begin{array}{l}\text { Significance } \\
\text { (1-tailed) }\end{array}$} & \multicolumn{3}{|l|}{ Means } \\
\hline & & & Expectation & Perception & Difference \\
\hline \multicolumn{6}{|l|}{ Study 2} \\
\hline $\begin{array}{l}\text { High- } \\
\text { rapport }\end{array}$ & $t=5.85$ & $\mathrm{p}<0.001$ & 5.54 & 6.01 & -0.47 \\
\hline $\begin{array}{c}\text { Moderate- } \\
\text { rapport }\end{array}$ & $t=6.02$ & $\mathrm{p}<0.001$ & 5.59 & 4.93 & 0.66 \\
\hline $\begin{array}{l}\text { Low- } \\
\text { rapport }\end{array}$ & $\begin{array}{l}\mathrm{t}= \\
22.27\end{array}$ & $\mathrm{p}<0.001$ & 5.54 & 2.80 & 2.74 \\
\hline \multicolumn{6}{|l|}{ Study 3} \\
\hline $\begin{array}{l}\text { High- } \\
\text { rapport }\end{array}$ & $\mathrm{t}=1.18$ & $\mathrm{p}=0.125$ & 5.52 & 5.88 & -0.36 \\
\hline $\begin{array}{l}\text { Moderate- } \\
\text { rapport }\end{array}$ & $\mathrm{t}=3.32$ & $\mathrm{p}=0.002$ & 5.44 & 6.15 & -0.71 \\
\hline $\begin{array}{l}\text { Low- } \\
\text { rapport }\end{array}$ & $\mathrm{t}=3.31$ & $\mathrm{p}=0.002$ & 5.96 & 4.89 & 1.07 \\
\hline
\end{tabular}

rapport and moderate-rapport scenarios.

Table 8 presents the one-tailed $t$-test results and the results showed that the dependent variable Satisfaction is significant $(t=7.38, p<$ 0.001 ), that there was a difference in participants' satisfaction between the high and moderate-rapport scenarios. The t-tests for all four dimensions of rapport, Enjoyable Interaction ( $\mathrm{t}=5.69, p<0.001$ ), Personal Connection ( $t=16.73, p<0.001$ ), Group Attentiveness $(\mathrm{t}=11.14, p<$ $0.001)$ and Service Congruity $(t=9.67, p<0.001)$ all showed significant results. Thus, the first set of t-tests showed that high tourist-tourist rapport increases satisfaction compared to moderate rapport.

The second set of t-tests was on the four dimensions of rapport and satisfaction between the low-rapport and moderate-rapport video scenarios (see Table 8). The $t$-test for Satisfaction $(t=7.82, p<0.001$ ) showed a significant difference in participants' satisfaction between the low and moderate-rapport scenarios. The t-tests for Enjoyable Interaction $(t=14.76, p<0.001)$, Personal Connection ( $t=11.94, p<0.001)$, Group Attentiveness $(t=7.28, p<0.001)$ and Service Congruity $(t=6.50, p<$ 0.001 ) all showed significant results. Thus, the two sets of t-tests provide support for $\mathrm{H} 2$.

Robustness of findings. Additional tests to verify the robustness of the t-tests compared the results for several demographic variables. Overall, the tests showed that the results are highly robust with no significant differences between participants of different ages, income, or educational backgrounds.

\subsection{Study 3: field experiment}

Study 3 is a field experiment that further assesses the extent to which tourist-tourist rapport impacts satisfaction with the group activity (i.e., H2). It complements and supports Study 2 by allowing participants to experience a real 3-h food tasting tour. The experimental realism of Study 3 provides high ecological validity.

\subsubsection{Method}

Field experiment design. The field experiment comprised nine food tours: three per condition of high, moderate (control group), and low tourist-tourist rapport. Each tour included four actors and eight to nine participants. The actors used scripts and improvisational options for each rapport condition to account for the presence of the participants whose behavior was not controlled. The actors played the same character but behaved differently in each rapport condition.

To eliminate possible confounding factors, an experienced tour guide who worked for the food tour firm conducted all tours, and was instructed to behave consistently friendly and professionally regardless of the behavior of the actors. Additionally, the other group tour elements (such as the food and drink, the walking route, and the restaurants) were identical and high quality across all tours. A rehearsal tour familiarized the four actors with the tour guide's commentary, the tour sequence, and the high, moderate, and low-rapport behaviors.

Data collection. Participants were recruited through social media and the authors' networks. Participants were provided with the very general aim of the research: to obtain feedback on the food tour rather than the specific aims. They were asked not to reveal their role to others and not let their role interfere with their usual behavior. Most participants participated as singles, with fewer than $10 \%$ as couples. Before the tour,

Table 8

Study 2 and 3 results of one-tailed $t$-test.

\begin{tabular}{|c|c|c|c|c|c|c|}
\hline \multirow[t]{2}{*}{ Variable } & \multirow[t]{2}{*}{ Test statistic } & \multirow[t]{2}{*}{ Significance (1-tailed) } & \multirow[t]{2}{*}{ Reject $\mathrm{H}_{0}$} & \multicolumn{3}{|c|}{ Means (Standard Deviation) } \\
\hline & & & & High & Moderate & Low \\
\hline \multicolumn{7}{|l|}{ H2 (high vs. moderate) } \\
\hline Personal Connection & $t=16.73$ & $\mathrm{p}<0.001$ & Yes & $6.09(0.70)$ & $4.43(1.23)$ & \\
\hline Group Attentiveness & $t=11.14$ & $\mathrm{p}<0.001$ & Yes & $5.91(1.05)$ & $3.81(1.41)$ & \\
\hline Service Congruity & $t=9.67$ & $\mathrm{p}<0.001$ & Yes & $6.06(0.80)$ & $5.04(1.27)$ & \\
\hline Personal Connection & $t=0.32$ & $\mathrm{p}=0.374$ & No & $4.92(1.02)$ & $4.82(1.13)$ & \\
\hline Group attentiveness & $t=2.87$ & $\mathrm{p}=0.003$ & Yes & $6.21(0.64)$ & $5.57(0.93)$ & \\
\hline Service Congruity & $\mathrm{t}=3.01$ & $\mathrm{p}=0.002$ & Yes & $6.44(0.74)$ & $5.72(0.99)$ & \\
\hline Satisfaction & $\mathrm{t}=1.98$ & $\mathrm{p}=0.027$ & - & $6.18(0.80)$ & $5.65(1.00)$ & \\
\hline \multicolumn{7}{|l|}{ H2 (low vs. moderate) } \\
\hline \multicolumn{7}{|l|}{ Study 2} \\
\hline \multicolumn{7}{|l|}{ Study 3} \\
\hline Enjoyable Interaction & $t=3.68$ & $\mathrm{p}<0.001$ & Yes & & $6.05(0.96)$ & $4.90(1.26)$ \\
\hline Personal Connection & $\mathrm{t}=1.89$ & $\mathrm{p}=0.032$ & Yes & & $4.82(1.13)$ & $4.13(1.47)$ \\
\hline Group attentiveness & $\mathrm{t}=3.52$ & $\mathrm{p}<0.000$ & Yes & & $5.57(0.93)$ & $4.47(1.30)$ \\
\hline Service Congruity & $t=4.66$ & $\mathrm{p}<0.000$ & Yes & & $5.72(0.99)$ & $4.41(1.04)$ \\
\hline Satisfaction & $\mathrm{t}=1.72$ & $\mathrm{p}=0.046$ & - & & $5.65(1.00)$ & $5.15(1.47)$ \\
\hline
\end{tabular}


participants completed a survey with questions about expectations. After the tour, participants completed a survey with the same questions used in Study 2 (see Table C). We obtained 79 responses: 25 for the moderate-rapport condition and 27 for the high and low-rapport conditions. Participants were on average 43 years old, $67 \%$ female, and $84 \%$ with a bachelor's degree or higher.

Procedure and manipulation checks. We performed the same manipulation and confounding checks as in Study 2. A one-tailed $t$-test through questions MN1 to MN3 (Cronbach's $\alpha=0.87$ ) showed that participants made a clear distinction between the high and moderate-rapport conditions $\left(M_{\text {high }}=6.40, S D=0.51, M_{\text {moderate }}=5.93, S D=0.94, t=2.22, p\right.$ $=0.016)$ and between the low and moderate-rapport conditions $\left(M_{\text {low }}=\right.$ $3.95, S D=1.45$, $\left.M_{\text {moderate }}=5.93, S D=0.94, t=5.80, p<0.001\right)$. A onetailed $t$-test through questions CF1 to CF3 (Cronbach's $\alpha=0.78$ ) showed a significant result for the high versus moderate-rapport condition $\left(M_{\text {high }}=6.81, S D=0.53, M_{\text {moderate }}=6.51, S D=0.74, t=1.74, p=\right.$ 0.044 ), but an insignificant result for the low versus moderate-rapport condition $\left(M_{\text {low }}=6.68, S D=0.51, M_{\text {moderate }}=6.51, S D=0.74, t=\right.$ $0.98, p=0.165)$. Although the tour guide strove to keep her behavior consistent, participants in the high-rapport condition rated her performance higher than in the moderate and low-rapport conditions. This maybe because the actors praised the tour guide in only the high-rapport tours and the praise may have affected the perceptions of the participants.

As in Study 2, we included a question that examined participants' expectations about other tourists before the tour and a similar question about their perceptions after the tour. The means of these two questions were compared through a paired $t$-test, split by rapport condition. As expected, there was a significant difference between participants' expectations and their perceptions for the high-rapport tours $(t=3.32, p=$ 0.002 ) and the low-rapport tours ( $t=3.31, p=0.002)$ (see Table 7). There was no significant difference between expectation and perception for the moderate-rapport tours ( $t=1.18, p=0.125)$, indicating that participants expected and experienced moderate tourist-tourist rapport.

\subsubsection{Analysis and results}

Assessment of levels of rapport on satisfaction. To assess $\mathrm{H} 2$, we performed two sets of one-tailed t-tests, the first set on the impact of touristtourist rapport on satisfaction between the high-rapport and moderaterapport (control) conditions. We used the same measures from Study 2, although two questions (SAT3 and SAT5) were removed from Satisfaction to attain an acceptable Cronbach's $\alpha$. All variables had high internal consistency: Satisfaction (Cronbach's $\alpha=0.94)$ Enjoyable Interaction (Cronbach's $\alpha=0.86)$, Group Attentiveness (Cronbach's $\alpha=0.89$ ), Personal Connection (Cronbach's $\alpha=0.77$ ), and Service Congruity (Cronbach's $\alpha=0.87$ ) (Bland \& Altman, 1997).

Table 8 presents the one-tailed $t$-test results for each variable. The $t$ test result for the dependent variable Satisfaction $(t=1.98, p=0.027$ ) showed a significant difference between the high-rapport and moderaterapport conditions. The t-tests for Enjoyable Interaction $(t=1.69, p=$ 0.049), Group Attentiveness ( $t=2.87, p=0.003$ ), and Service Congruity ( $t$ $=3.01, p=0.002$ ) all showed significant results while the $t$-test for Personal Connection ( $t=0.32, p=0.374$ ) showed an insignificant result. These results indicated that while Enjoyable Interaction, Group Attentiveness, and Service Congruity increased Satisfaction, this was not the case for Personal Connection. A likely explanation is that the participants' behavior was not controlled, and a participant could make personal connections with other participants even though the four actors in the moderate-rapport condition were reserved and avoided making connections.

The second set of t-tests compared the low-rapport and moderaterapport (control) conditions (see Table 8). The $t$-test for Satisfaction showed a significant result $(\mathrm{t}=1.72, \mathrm{p}<0.046)$. The t-tests for Enjoyable Interaction $(\mathrm{t}=3.68, \mathrm{p}<0.001)$, Group Attentiveness $(\mathrm{t}=3.52, \mathrm{p}<$ 0.001), Personal Connection $(\mathrm{t}=1.89, \mathrm{p}=0.032)$, and Service Congruity $(\mathrm{t}=4.66, \mathrm{p}<0.001)$ showed significant results. The results from the two sets of t-tests provide support for $\mathrm{H} 2$ between the low and moderaterapport conditions and partial support for $\mathrm{H} 2$ between the high and moderate-rapport conditions, due to the insignificant result for Personal Connection. Overall, although the results of Study 3 partially support $\mathrm{H} 2$, the findings largely held for this real 3-h food tour, thereby providing external validation for Study 2 .

\section{Discussion and implications}

Existing research highlights the importance of rapport (customeremployee and customer-customer) in non-group contexts in services and tourism. Yet, there is a dearth of studies that empirically assesses rapport in group contexts where tourists consume with other tourists. Motivated by this, we used a sequential, three-study mixed method approach to answer two questions. One, what are the important dimensions of tourist-tourist rapport in guided group activities? And two, using these dimensions, does getting along with other tourists in guided group activities matter to satisfaction? We now outline implications of our findings for research and practice.

\subsection{Theoretical implications}

The first major theoretical contribution is that rapport between tourists in group contexts is more multidimensional than previously conceptualized for customer-employee rapport and customer-customer rapport in non-group contexts. More specifically, we find that touristtourist rapport in guided group activities comprises two dyadic dimensions (Personal Connection and Enjoyable Interaction) and two new group-based dimensions (Service Congruity and Group Attentiveness). As a result, we define tourist-tourist rapport as a tourist's perception of getting along with fellow tourists in the group, characterized by similarity of views about the service, mutual attentiveness, and having enjoyable interactions and personal connections with group members.

The identification of the Service Congruity dimension highlights the importance of understanding how similarity with (or divergence from) other tourists' views toward a service can foster trust (or distrust) among tourists (Choi \& Mattila, 2018; Wu et al., 2016). The Group Attentiveness dimension reflects the importance of customers expecting their group members to show consideration and interest toward one another (Bernieri et al., 1996). Our paper is the first to theoretically and qualitatively derive these group-based dimensions of rapport and empirically examine their impact.

A second contribution concerns our conceptualization of touristtourist rapport for guided group activities involving dyadic dimensions (Enjoyable Interaction and Personal Connection) that mediate the relationship between group-based dimensions (Service Congruity and Group Attentiveness) with satisfaction. This process and sequencing aspect of rapport follow Tickle-Degnen and Rosenthal (1990), who argue that people have better experiences with each other when positivity and mutual attention (similar to Service Congruity and Group Attentiveness) occur in the early stages of rapport, and coordination (similar to Enjoyable Interaction and Personal Connection) occurs in the later stages. This notion of a rapport process and sequencing is similar to the evolving feeling of communion found in river rafting trips (Arnould \& Price, 1993). In sum, our conceptualization of rapport helps to better understand its complexity, process, and causal consequences.

A third contribution is our research addresses calls in services and tourism literature (e.g., Macintosh, 2009; Qiu, Li, Shu, \& Bai, 2020) to delve more deeply into the contextualization of rapport. Consistent with the principles of contingency theory (Donaldson, 2001), the rapport construct in one service context (e.g., customer-employee relationships in non-group contexts) may need to be adapted to be appropriately applied to other service contexts (e.g., tourist-tourist relationships in group contexts). This adds to and redirects research focused only on dyadic contexts (i.e., customer-employee and customer-customer, see: Hyun \& Kim, 2014; Kaminakis et al., 2019). It also highlights the 
importance of group-related motivations for rapport behaviors. For example, Finsterwalder and Kuppelwieser (2011) found that cooperation in task activity is necessary for customer groups to connect socially, and not just customer-employee rapport leading to commercial gain (i. e., tipping employees). This social cooperation likely equates to the group-based dimensions of rapport in our study. In this sense, our research contributes to the theoretical development of the customer-customer interaction literature and serves as a foundation for future research examining such interactions in a range of group services.

Finally, our study shows that getting along with other tourists in guided group activities is a "critical factor" (Johnston, 1995), in that it is both a satisfier (high rapport increases satisfaction) and a dissatisfier (low rapport decreases satisfaction). Even when the other elements of the group activity (e.g., tour guide, food and physical spaces, and organization) are already first-rate, moderate to high levels of tourist-tourist rapport can further increase overall satisfaction. So even though positive tourist-tourist interactions in group services positively impact satisfaction (Lin, Zhang, Gursoy, \& Fu, 2019; Wu, 2007), the level of positive interaction had not been examined previously. Further, our results suggest that when tourist-tourist rapport is low, this reduces satisfaction, even if the other elements of the group activity remain first-rate. Prior research had considered rapport as a satisfier only and had not considered the impact of low rapport (e.g., Gremler \& Gwinner, 2000, 2008; Kim \& Baker, 2019).

\subsection{Practical implications}

Our findings have implications for managers who design group activities, guides who deliver them, and tourists who participate in them. While many managers will be aware that tourists expect to have rapport with their fellow tourists, they are unlikely to take its multidimensionality into account in their design and delivery of a group activity.

To encourage Service Congruity, the design of the group activity could schedule time for tourists to share their positive impressions of an aspect of the experience (e.g., asking tourists which food tasting was their favorite). Managers could train and empower guides to capitalize on unexpected, pleasurable "peak" events (Dixon, Victorino, Kwortnik, \& Verma, 2017) that build collective group enthusiasm (e.g., stopping the bus so tourists can see a wildlife event). Conversely, guides could be trained and empowered to diplomatically remove unhappy or disruptive tourists and offer them a refund before they can disturb the group's enthusiasm. Further, marketing communications for the guided group activity could be designed to ensure tourists have the information they need to help them choose the group activity that best matches their interests and abilities.

To foster Group Attentiveness, there could be planned opportunities in which group members converse with each other and engage in tasks in which they cooperate (e.g., ice-breaker exercises or games). As both Service Congruity and Group Attentiveness help develop Enjoyable Interaction and Personal Connection, cultivating these group-based dimensions could be scheduled in the initial stages of the guided group activity.

For Enjoyable Interaction, we suggest providing opportunities for oneon-one conversations between tourists after some group-based interaction i.e., after some Service Congruity and Group Attentiveness events. Examples could include allowing tourists to speak to each other while walking from one location to another or having the guide introduce individuals or couples to other individuals or couples that they might like. Guides would also have the skill, training, and empowerment to recognize, deflect, and reframe disagreeable tourist-tourist interactions to prevent and eliminate discord.

To develop Personal Connection, the group activity could be designed to ensure tourists share information about themselves such as where they are from and their reasons for participating in the group activity. In this vein, Hwang, Kim, and Hyun (2013) found that mutual disclosure positively impacts customer-employee rapport. Similarly, guides might be apprised of group member backgrounds beforehand and/or learn about them during the activity to identify potential Personal Connections among tourists.

\subsection{Limitations and future research}

For Studies 2 and 3, we sought to ensure good experimental settings and control by focusing on group food tours. A limitation of this focus is that it potentially restricts the generalizability of our findings, although our findings are consistent with previous literature. Thus, future research could advance our insights into different group contexts that vary in terms of activity duration, level and type of tourist-tourist interaction, and nature of the activity (e.g., sightseeing versus adventure recreation).

The choice of the video experiment in Study 2 is appropriate for building on Study 1 and testing our hypotheses. However, it is recognized that a video of a group activity is a condensed and artificial representation with participants imagining themselves in the activity rather than experiencing the activity. Although we addressed this limitation with the field experiment in Study 3, virtual reality technology methods could be considered (Meiren \& Burger, 2010).

As our research was conducted in North America, the findings may be limited to this regional context. There would be merit in examining tourist-tourist rapport in different cultures, as the impact of relational interactions in tourist activities will differ across countries (Nicholls, 2011; Yuksel, Kilinc, \& Yuksel, 2006). In addition, as characteristics of individuals (e.g., age, gender, nationality, and culture) can influence how groups interact and perform tasks (Watson, Kumar, \& Michaelsen, 1993), these characteristics could also affect tourist-tourist rapport. This area of research would be especially interesting for firms that can control their customer mix through an online booking system that includes screening questions.

Finally, it could be beneficial for future research to examine the process and sequencing aspects of tourist-tourist rapport in guided group activities like designing the sequence and flow of a service encounter (Verhoef, Antonides, \& De Hoog, 2004). This would help to understand how rapport develops and changes over time, and how it is impacted by the duration of the guided group activity. Research on the timing and coordinating of service experiences indicates that the final stages of a service experience significantly impact satisfaction (Redelmeier \& Kahneman, 1996). Future research could assess how different dimensions of tourist-tourist rapport can vary at different stages of the group activity and how this sequencing affects satisfaction.

Table A

Study 1 manager, tourist, and guide interviews

\begin{tabular}{|c|c|c|c|c|}
\hline Manager* & $\begin{array}{l}\text { Guided Group } \\
\text { Activity }\end{array}$ & $\begin{array}{l}\text { No. of } \\
\text { Tourists in } \\
\text { Group }\end{array}$ & $\begin{array}{l}\text { Service } \\
\text { Duration }\end{array}$ & $\begin{array}{l}\text { Age of } \\
\text { Tourists }\end{array}$ \\
\hline F1 & Cooking lessons & 22 & $4 \mathrm{~h}$ & 23 to 65 \\
\hline F2 & $\begin{array}{l}\text { Food/wine tours } \\
\text { and events }\end{array}$ & $3-26$ & $\begin{array}{l}2 \text { hours-3 } \\
\text { days }\end{array}$ & 30 to 70 \\
\hline F3 & Wine tasting/tours & $10-20$ & $45 \mathrm{~min}$ & 19 to 80 \\
\hline F4 & $\begin{array}{l}\text { Hiking/outdoor } \\
\text { tours }\end{array}$ & 6 & $4 \mathrm{~h}$ & No answer \\
\hline F5 & Vineyard dinners & $40-42$ & $3-4 \mathrm{~h}$ & 40 to 60 \\
\hline F6 & $\begin{array}{l}\text { Wine/cooking } \\
\text { lessons }\end{array}$ & $15-26$ & $4-45 \mathrm{~h}$ & $18+$ \\
\hline F7 & $\begin{array}{l}\text { Winery tours/ } \\
\text { concerts }\end{array}$ & $50-70$ & $3 \mathrm{~h}$ & $50+$ \\
\hline F8 & $\begin{array}{l}\text { Improvisation } \\
\text { workshops }\end{array}$ & $15-20$ & $2-3 \mathrm{~h}$ & 20 to 60 \\
\hline Tourist** $^{* *}$ & Gender & \multicolumn{3}{|c|}{ Recent Guided Group Activities } \\
\hline T1 & $\mathrm{F}$ & \multicolumn{3}{|c|}{ One food tour, one packaged tour } \\
\hline $\mathrm{T} 2$ & $\mathrm{~F}$ & \multicolumn{3}{|c|}{ One food tour } \\
\hline T3 & $\mathrm{F}$ & \multicolumn{3}{|c|}{ One food tour, four other group tours } \\
\hline
\end{tabular}


Table A (continued)

\begin{tabular}{|c|c|c|c|c|}
\hline Tourist** & Gender & \multicolumn{3}{|c|}{ Recent Guided Group Activities } \\
\hline T4 & M & \multicolumn{3}{|c|}{ Two food tours, one city tour } \\
\hline T5 & $\mathrm{F}$ & \multicolumn{3}{|c|}{ Two food tours, two city tours, two museum tours } \\
\hline T6 & $\mathrm{F}$ & \multicolumn{3}{|c|}{ One food tour } \\
\hline $\mathrm{T} 7$ & M & \multicolumn{3}{|c|}{ Two food tours, ten city tours } \\
\hline T8 & M & \multicolumn{3}{|c|}{ Two food tours, one brewery tour } \\
\hline T9 & $\mathrm{F}$ & \multicolumn{3}{|c|}{ One city tour, four city tours } \\
\hline $\mathrm{T} 10$ & M & \multicolumn{3}{|c|}{ One food tour, one packaged tour } \\
\hline $\mathrm{T} 11$ & $\mathrm{~F}$ & \multicolumn{3}{|c|}{ Two food tours, one winery tour, two nature tours } \\
\hline $\mathrm{T} 12$ & G & \multicolumn{3}{|c|}{ One food tour, three nature tours } \\
\hline Guide*** & Type of Tours & $\begin{array}{l}\text { Location of } \\
\text { Tours }\end{array}$ & $\begin{array}{l}\text { Years of } \\
\text { Experience }\end{array}$ & $\begin{array}{l}\text { Age of } \\
\text { Tourists }\end{array}$ \\
\hline G1 & $\begin{array}{l}\text { Partial and one-day } \\
\text { walking and cycle } \\
\text { tours }\end{array}$ & Local & 1 & 15 to 60 \\
\hline G2 & $\begin{array}{l}\text { Two-hour } \\
\text { photography tours }\end{array}$ & Local & 2 & $18+$ \\
\hline G3 & $\begin{array}{l}\text { Multi-day holiday } \\
\text { tours }\end{array}$ & International & 35 & 35 to 75 \\
\hline G4 & $\begin{array}{l}\text { Multi-day holiday } \\
\text { tours }\end{array}$ & Domestic & 5 & $35+$ \\
\hline G5 & One-day cycle tours & Local & 3 & $20 s-60 s$ \\
\hline G6 & $\begin{array}{l}\text { One- and multi-day } \\
\text { holiday tours }\end{array}$ & Domestic & 42 & 30 to 70 \\
\hline G7 & $\begin{array}{l}\text { Multi-day holiday } \\
\text { tours }\end{array}$ & Domestic & 16 & 55 to 70 \\
\hline G8 & $\begin{array}{l}\text { Multi-day holiday } \\
\text { tours }\end{array}$ & Domestic & 5 & 20 to 80 \\
\hline G9 & $\begin{array}{l}\text { Two to } 3 \text {-h food } \\
\text { walking tours }\end{array}$ & Local & 6 & $20 s-70 s$ \\
\hline G10 & $\begin{array}{l}\text { One- and multi-day } \\
\text { holiday tours }\end{array}$ & Domestic & 14 & Seniors \\
\hline
\end{tabular}

\section{Sampling criteria.}

*Managers were from firms that organize commercial group experiences in the tourism and leisure sectors, considered leaders in their field, as determined by referrals from experts and from the network of the first author who had previously worked in the tourism industry.

$* *$ Tourists were randomly selected recent customers of a food tour company.

$* * *$ Experienced tour guides were selected from a national tour guide association and from the network of the first author.

Table B

Study 2 preparation and outline of video scenarios

Video preparation and pretesting
Screenplay
A screenplay was developed based on the tour guide script
from the food company. Tourists' roles reflect the range for
each dimension of tourist-tourist rapport (high, moderate,
and low).
Videos were shot at a restaurant in the actual food tour usi
a professional videographer, six trained actors, and a tour
guide from the food tour firm. The actors each received back
stories and direction on facial expressions, body language,
and dialogue for each scenario.
Screenplays were tested with 12 respondents and then
revised to improve clarity. The videos were tested in two
rounds; first by involving 25 respondents (25+ years old,
participated in paid group activity), and then through 20
graduate students.

\section{Outline of video scenarios}

Tour welcome Tour guide is standing outside with six tourists. She welcomes the tourists, gives them an overview of the tour, and ask them to give their names, where they are from, and their favorite guilty pleasure food. The camera begins with a wide shot of the group and then close shots of each person's face and upper torso as they are speaking.

High: Tourists smile broadly, look at the group, and provide additional personal details in their introductions while others smile back at them.

Moderate: Tourists smile briefly, are subdued and provide perfunctory introductions. Low: One tourist arrives late and interrupts the guide, and another tourist looks at his cell
Table B (continued)

\begin{tabular}{|c|c|c|}
\hline & & $\begin{array}{l}\text { phone and ignores the group, while the others } \\
\text { behave as in the moderate scenario. }\end{array}$ \\
\hline \multirow[t]{4}{*}{$\begin{array}{l}\text { Entering } \\
\text { restaurant }\end{array}$} & \multicolumn{2}{|c|}{$\begin{array}{l}\text { Tour guide enters first into the restaurant and tourists follow. } \\
\text { The camera shows the entire group, showing their faces and } \\
\text { torsos. }\end{array}$} \\
\hline & High: & $\begin{array}{l}\text { One tourist smiles and holds the door open for } \\
\text { all other tourists, who smile at him. }\end{array}$ \\
\hline & Moderate: & $\begin{array}{l}\text { Each tourist holds the door open for the next } \\
\text { tourist without smiling. }\end{array}$ \\
\hline & Low: & $\begin{array}{l}\text { One tourist cuts in line as they enter the } \\
\text { restaurant. }\end{array}$ \\
\hline \multirow[t]{4}{*}{ Food tasting } & \multicolumn{2}{|c|}{$\begin{array}{l}\text { Tour guide and tourists are seated around a round table on } \\
\text { which the food and drink tastings have been placed. The } \\
\text { guide talks about the restaurant, the chef, and the food and } \\
\text { drink they will be tasting. }\end{array}$} \\
\hline & High: & $\begin{array}{l}\text { Tourists contribute information they know } \\
\text { about the chef, they smile and laugh with each } \\
\text { other, make appreciative sounds as they taste } \\
\text { the food, and talk about how impressed they } \\
\text { are. The camera pans the group, then focuses } \\
\text { on the speaker's face along with one or two } \\
\text { people on either side. }\end{array}$ \\
\hline & Moderate: & $\begin{array}{l}\text { Tourists smile at the food and drink but they } \\
\text { do not speak to others. }\end{array}$ \\
\hline & Low: & $\begin{array}{l}\text { One tourist argues with her husband, does not } \\
\text { eat some of the food, and questions the calorie } \\
\text { count and choice of food, two tourists make } \\
\text { faces in reaction to the arguing couple, while } \\
\text { the others behave as in the moderate scenario. }\end{array}$ \\
\hline $\begin{array}{l}\text { Map and } \\
\text { description of } \\
\text { route }\end{array}$ & \multicolumn{2}{|c|}{$\begin{array}{l}\text { The screen depicts the full food tour by showing a map of the } \\
\text { route with the location of the five restaurants, while the } \\
\text { guide (in voiceover) describes the tastings for each } \\
\text { restaurant, and that the tour takes } 3 \mathrm{~h} \text { in total. This scene is } \\
\text { the same for all scenarios. }\end{array}$} \\
\hline \multirow[t]{4}{*}{ Tour conclusion } & \multicolumn{2}{|c|}{$\begin{array}{l}\text { The tour guide is standing outside with six tourists. After the } \\
\text { tourists interact as below, the guide makes concluding } \\
\text { remarks and thanks the tourists. The camera shows a wide } \\
\text { shot of the group and focuses on the speaker's face along } \\
\text { with one or two people on either side. }\end{array}$} \\
\hline & High: & $\begin{array}{l}\text { Tourists share personal stories about their } \\
\text { families, discuss common interests, and } \\
\text { comment on how much they enjoyed the tour. }\end{array}$ \\
\hline & Moderate: & $\begin{array}{l}\text { Tourists mill about the tour guide, smile } \\
\text { briefly, but do not interact. }\end{array}$ \\
\hline & Low: & $\begin{array}{l}\text { Two tourists have a disagreement about } \\
\text { restaurant reviews, one behaving dismissively } \\
\text { and the other acting offended. }\end{array}$ \\
\hline
\end{tabular}

Table C

Questions and constructs for study 2 and study 3

\begin{tabular}{lll}
\hline Type & Question & Reference \\
\hline $\begin{array}{l}\text { Expectation and Perception (EXP1 asked before viewing video/going on tour) } \\
\text { EXP1 }\end{array} \begin{array}{ll}\text { I would expect the other customers on } \\
\text { the tour to be enjoyable to be around. }\end{array}$ & $\begin{array}{l}\text { Study 1, Gremler and Gwinner } \\
\text { (2000) }\end{array}$ \\
PER1 & $\begin{array}{l}\text { The other customers were enjoyable } \\
\text { to be around. }\end{array}$ \\
Satisfaction \\
SAT1 $\quad \begin{array}{l}\text { The quality of the overall experience } \\
\text { by ... is }\end{array}$
\end{tabular}

(continued on next page) 
Table C (continued)

\begin{tabular}{|c|c|c|}
\hline Type & Question & Reference \\
\hline & $\begin{array}{l}\text { On the whole, I felt other customers } \\
\text { liked the tour. }\end{array}$ & \\
\hline \multicolumn{3}{|c|}{ Group Attentiveness } \\
\hline GA1 & $\begin{array}{l}\text { On the whole, I felt other customers } \\
\text { on the tour were interested in talking } \\
\text { to each other. }\end{array}$ & $\begin{array}{l}\text { Study 1, Gremler and Gwinner } \\
\text { (2008), Tickle-Degnen and } \\
\text { Rosenthal (1990) }\end{array}$ \\
\hline GA2 & $\begin{array}{l}\text { On the whole, I felt other customers } \\
\text { on the tour were not interested in } \\
\text { talking to me. }\end{array}$ & \\
\hline GA3 & $\begin{array}{l}\text { On the whole, I felt other customers } \\
\text { on the tour were not interested in } \\
\text { talking to each other. }\end{array}$ & \\
\hline GA4 & $\begin{array}{l}\text { On the whole, I felt other customers } \\
\text { on the tour were interested in talking } \\
\text { to me. }\end{array}$ & \\
\hline GA5 & $\begin{array}{l}\text { On the whole, I felt other customers } \\
\text { on the tour were helpful. }\end{array}$ & $\begin{array}{l}\text { Study 1, Tickle-Degnen and } \\
\text { Rosenthal (1990) }\end{array}$ \\
\hline \multicolumn{3}{|c|}{ Enjoyable Interaction } \\
\hline EI1 & $\begin{array}{l}\text { On the whole, I felt uncomfortable } \\
\text { with other customers on the tour. }\end{array}$ & $\begin{array}{l}\text { Study 1, Wu (2007), Gremler and } \\
\text { Gwinner (2000) }\end{array}$ \\
\hline EI2 & $\begin{array}{l}\text { On the whole, I liked other customers } \\
\text { on the tour. }\end{array}$ & \\
\hline EI3 & $\begin{array}{l}\text { On the whole, I felt other customers } \\
\text { on the tour were polite. }\end{array}$ & \\
\hline EI4 & $\begin{array}{l}\text { On the whole, I felt comfortable with } \\
\text { other customers on the tour. }\end{array}$ & \\
\hline EI5 & $\begin{array}{l}\text { I would have preferred to have taken } \\
\text { the tour by myself without other } \\
\text { customers. }\end{array}$ & \\
\hline EI6 & $\begin{array}{l}\text { On the whole, I disliked other } \\
\text { customers on the tour. }\end{array}$ & \\
\hline EI7 & $\begin{array}{l}\text { On the whole, I felt other customers } \\
\text { on the tour were rude. }\end{array}$ & \\
\hline EI8 & $\begin{array}{l}\text { I'm glad I took this tour in the } \\
\text { company of other customers. }\end{array}$ & \\
\hline \multicolumn{3}{|c|}{ Personal Connection } \\
\hline PC1 & $\begin{array}{l}\text { I felt customers on the tour did not } \\
\text { have anything personal in common. }\end{array}$ & Study 1, Huang \& Hsu (2010) \\
\hline PC2 & $\begin{array}{l}\text { I felt some customers on the tour had } \\
\text { something personal in common. }\end{array}$ & \\
\hline PC3 & $\begin{array}{l}\text { I felt friendships were not developed } \\
\text { with any customers on the tour. }\end{array}$ & $\begin{array}{l}\text { Study 1, Gremler and Gwinner } \\
(2000)\end{array}$ \\
\hline PC4 & $\begin{array}{l}\text { I felt friendships were developed with } \\
\text { some customers on the tour. }\end{array}$ & \\
\hline \multicolumn{3}{|c|}{ Manipulation Checks } \\
\hline MN1 & $\begin{array}{l}\text { How negative or positive was the } \\
\text { behavior of other customers on the } \\
\text { tour? }\end{array}$ & \\
\hline MN2 & $\begin{array}{l}\text { The other customers made the tour } \\
\text { better. }\end{array}$ & \\
\hline MN3 & $\begin{array}{l}\text { The other customers made the tour } \\
\text { worse. }\end{array}$ & \\
\hline \multicolumn{3}{|c|}{ Confounding Checks } \\
\hline CF1 & $\begin{array}{l}\text { The tour guide was courteous at all } \\
\text { times. }\end{array}$ & \\
\hline $\mathrm{CF} 2$ & The tour guide made the tour worse. & \\
\hline CF3 & The tour guide made the tour better. & \\
\hline
\end{tabular}

Notes: a) The name of the food tour company was used in the questionnaire.

b) Questions SAT3 and SAT5 were removed for study 3 to improve Cronbach's $\alpha$

\section{Credit author contribution statement}

Linda W. Lee; contributed to the Conceptualization, literature review, qualitative and quantitative data collection, Formal analysis of the qualitative and quantitative data, and writing. Edward Boon; contributed to the Conceptualization, literature review, quantitative data collection, Formal analysis of the qualitative and quantitative data, and writing. Ian P. McCarthy; contributed to the Conceptualization, literature review, quantitative data collection, Formal analysis of the qualitative data, writing, and Funding acquisition.

\section{Impact statement}

Guided group activities are a common and important tourism activity. Yet, there is limited research on the multidimensionality of rapport in these activities and how this impacts satisfaction. We unpack rapport into two dyadic dimensions (Enjoyable Interaction and Personal Connection) and two new group-based dimensions (Group Attentiveness and Service Congruity). When a firm can facilitate and coordinate interactions for each of these dimensions, tourists are more satisfied, more loyal, and more likely to recommend, even when all other aspects of the service delivery are already first-rate. This provides insight into how tourism businesses and destination management organizations can facilitate their customers to develop rapport with fellow tourists and, in doing so, enhance their guided group experience.

\section{Declarations of competing interest}

None.

\section{Acknowledgments}

This research was supported by grants from CPA Innovation Centre, Simon Fraser University and Nottingham Trent University.

\section{References}

Aguinis, H., Villamor, I., \& Ramani, R. S. (2020). MTurk research: Review and recommendations. Journal of Management, 47(4), 823-837.

Altinay, L., Song, H., Madanoglu, M., \& Wang, X. L. (2019). The influence of customer-tocustomer interactions on elderly consumers' satisfaction and social well-being. International Journal of Hospitality Management, 78, 223-233.

Arnould, E. J., \& Price, L. L. (1993). River magic: Extraordinary experience and the extended service encounter. Journal of Consumer Research, 20(1), 24-45.

Bagozzi, R. P., \& Yi, Y. (1988). On the evaluation of structural equation models. Journal of the Academy of Marketing Science, 16(1), 74-94.

Bentler, P. M. (1990). Comparative fit indexes in structural models. Psychological Bulletin, 107(2), 238.

Bernieri, F. J., Gillis, J. S., Davis, J. M., \& Grahe, J. E. (1996). Dyad rapport and the accuracy of its judgment across situations: A lens model analysis. Journal of Personality and Social Psychology, 71(1), 110-129.

Bitner, M. J., Booms, B. H., \& Tetreault, M. S. (1990). The service encounter: Diagnosing favorable and unfavorable incidents. Journal of Marketing, 54(1), 71-84.

Bland, J. M., \& Altman, D. G. (1997). Statistics notes: Cronbach's alpha. BMJ, 314, 572.

Buhrmester, M., Kwang, T., \& Gosling, S. D. (2016). Amazon's mechanical Turk: A new source of inexpensive, yet high-quality data? Methodological Issues and Strategies in Clinical Research, 133-139.

Byrne, D., Griffitt, W., \& Stefaniak, D. (1967). Attraction and similarity of personality characteristics. Journal of Personality and Social Psychology, 5(1), 82-90.

Cai, R. R., Lu, L., \& Gursoy, D. (2018). Effect of disruptive customer behaviors on others' overall service experience: An appraisal theory perspective. Tourism Management, 69, 330-344.

Casidy, R., Wymer, W., \& O'Cass, A. (2018). Enhancing hotel brand performance through fostering brand relationship orientation in the minds of consumers. Tourism Management, 66, 72-84.

Chang, S. Y., Tsaur, S. H., Yen, C. H., \& Lai, H. R. (2020). Tour member fit and tour member-leader fit on group package tours: Influences on tourists' positive emotions, rapport, and satisfaction. Journal of Hospitality and Tourism Management, 42, 235-243.

Chhetri, P., Arrowsmith, C., \& Jackson, M. (2004). Determining hiking experiences in nature-based tourist destinations. Tourism Management, 25(1), 31-43.

Choi, S., \& Mattila, A. S. (2018). The effect of experience congruity on repurchase intention: The moderating role of public commitment. Service Science, 10(2), $124-138$.

Creswell, J. W., Klassen, A. C., Plano Clark, V. L., \& Smith, K. C. (2011). Best practices for mixed methods research in the health sciences. Bethesda (Maryland): National Institutes of Health.

Dabholkar, P. A., Shepherd, C. D., \& Thorpe, D. I. (2000). A comprehensive framework for service quality: An investigation of critical conceptual and measurement issues through a longitudinal study. Journal of Retailing, 76(2), 139-173.

DeWitt, T., \& Brady, M. K. (2003). Rethinking service recovery strategies: The effect of rapport on consumer responses to service failure. Journal of Service Research, 6(2), 193-207.

Dixon, M. J., Victorino, L., Kwortnik, R. J., \& Verma, R. (2017). Surprise, anticipation, and sequence effects in the design of experiential services. Production and Operations Management, 26(5), 945-960.

Donaldson, L. (2001). The contingency theory of organizations. Sage. 
Drolet, A. L., \& Morris, M. W. (2000). Rapport in conflict resolution: Accounting for how face-to-face contact fosters mutual cooperation in mixed-motive conflicts. Journal of Experimental Social Psychology, 36(1), 26-50.

Duck, S. (1994). Meaningful relationships: Talking sense and relating. London: Sage.

Eggert, A., Steinhoff, L., \& Garnefeld, I. (2015). Managing the bright and dark sides of status endowment in hierarchical loyalty programs. Journal of Service Research, 18 (2), 210-228.

Falter, M., \& Hadwich, K. (2020). Customer service well-being: Scale development and validation. Service Industries Journal, 40(1-2), 181-202.

Finsterwalder, J., \& Kuppelwieser, V. G. (2011). Co-creation by engaging beyond oneself: The influence of task contribution on perceived customer-to-customer social interaction during a group service encounter. Journal of Strategic Marketing, 19(7), 607-618.

Fornell, C., \& Larcker, D. F. (1981). Evaluating structural equation models with unobservable variables and measurement error. Journal of Marketing Research, 18(1), 39-50.

Gremler, D. D., \& Gwinner, K. P. (2000). Customer-employee rapport in service relationships. Journal of Service Research, 3(1), 82-104.

Gremler, D. D., \& Gwinner, K. P. (2008). Rapport-building behaviors used by retail employees. Journal of Retailing, 84(3), 308-324.

Grove, S. J., \& Fisk, R. P. (1997). The impact of other customers on service experiences: A critical incident examination of "getting along". Journal of Retailing, 73(1), 63-85.

Hair, J. F., Celsi, M., Ortinau, D. J., \& Bush, R. P. (2010). Essentials of marketing research (Vol. 2). New York, New York: McGraw-Hill/Irwin.

Hansen, A. H., \& Mossberg, L. (2017). Tour guides' performance and tourists' immersion: Facilitating consumer immersion by performing a guide plus role. Scandinavian Journal of Hospitality and Tourism, 17(3), 259-278.

Harrigan, P., Evers, U., Miles, M., \& Daly, T. (2017). Customer engagement with tourism social media brands. Tourism Management, 59, 597-609.

Hart, K. M., Capps, H. R., Cangemi, J. P., \& Caillouet, L. M. (1986). Exploring organizational trust and its multiple dimensions: A case study of general motors. Organization Development Journal, 4(2), 31-39.

Horng, J. S., \& Tsai, C. T. S. (2010). Government websites for promoting east asian culinary tourism: A cross-national analysis. Tourism Management, 31(1), 74-85.

Huang, J., \& Hsu, C. H. (2009). Interaction among fellow cruise passengers: Diverse experiences and impacts. Journal of Travel \& Tourism Marketing, 26(5-6), 547-567.

Huang, S., Hsu, C. H., \& Chan, A. (2010). Tour guide performance and tourist satisfaction: A study of the package tours in shanghai. Journal of Hospitality \& Tourism Research, 34(1), 3-33.

Huang, W. H., \& Wang, Y. C. (2014). Situational influences on the evaluation of other customer failure. International Journal of Hospitality Management, 36, 110-119.

Hu, L. T., \& Bentler, P. M. (1998). Fit indices in covariance structure modeling: Sensitivity to underparameterized model misspecification. Psychological Methods, 3 (4), 424.

Hu, L. T., \& Bentler, P. M. (1999). Cutoff criteria for fit indexes in covariance structure analysis: Conventional criteria versus new alternatives. Structural Equation Modeling: A Multidisciplinary Journal, 6(1), 1-55.

Hwang, J., Kim, S. S., \& Hyun, S. S. (2013). The role of server-patron mutual disclosure in the formation of rapport with and revisit intentions of patrons at full-service restaurants: The moderating roles of marital status and educational level. International Journal of Hospitality Management, 33, 64-75.

Hwang, J., \& Lee, J. H. J. (2019). Understanding customer-customer rapport in a senior group package context. International Journal of Contemporary Hospitality Management, 31(5), 2187-2204.

Hwang, Y., \& Mattila, A. S. (2018). Is it my luck or loyalty? The role of culture on customer preferences for loyalty reward types. Journal of Travel Research, 57(6), 769-778.

Hyun, S. S., \& Kim, I. (2014). Identifying optimal rapport-building behaviors in inducing patrons' emotional attachment in luxury restaurants. Journal of Hospitality \& Tourism Research, 38(2), 162-198.

Islam, J. U., Rahman, Z., \& Hollebeek, L. D. (2018). Consumer engagement in online brand communities: A solicitation of congruity theory. Internet Research, 28(1) 23-45.

Johnston, R. (1995). The determinants of service quality: Satisfiers and dissatisfiers. International Journal of Service Industry Management, 6(5), 53-71.

Kaminakis, K., Karantinou, K., Koritos, C., \& Gounaris, S. (2019). Hospitality servicescape effects on customer-employee interactions: A multilevel study. Tourism Management, 72, 130-144.

Kim, K., \& Baker, M. A. (2019). How the employee looks and looks at you: Building customer-employee rapport. Journal of Hospitality \& Tourism Research, 43(1), 20-40.

Kim, K., Byon, K., \& Baek, W. (2020). Customer-to-customer value co-creation and codestruction in sporting events. Service Industries Journal, 40(9-10), 633-655.

Kim, W., \& Ok, C. (2010). Customer orientation of service employees and rapport: Influences on service-outcome variables in full-service restaurants. Journal of Hospitality \& Tourism Research, 34(1), 34-55.

Kim, H., \& Qu, H. (2019). Employees' burnout and emotional intelligence as mediator and moderator in the negative spiral of incivility. International Journal of Contemporary Hospitality Management, 31(3), 1412-1431.

Levy, S. E., Getz, D., \& Hudson, S. (2011). A field experimental investigation of managerially facilitated consumer-to-consumer interaction. Journal of Travel \& Tourism Marketing, 28(6), 656-674.
Lin, H., Gursoy, D., \& Zhang, M. (2020). Impact of customer-to-customer interactions on overall service experience: A social servicescape perspective. International Journal of Hospitality Management, 87(May), 102376.

Lin, H., Zhang, M., Gursoy, D., \& Fu, X. (2019). Impact of tourist-to-tourist interaction on tourism experience: The mediating role of cohesion and intimacy. Annals of Tourism Research, 76, 153-167.

Long, L. M. (2013). Culinary tourism. Springer Netherlands.

Luong, A. (2005). Affective service display and customer mood. Journal of Service Research, 8(2), 117-130.

Macintosh, G. (2009). The role of rapport in professional services: Antecedents and outcomes. Journal of Services Marketing, 23(2), 70-78.

Mattila, A. S., Grandey, A. A., \& Fisk, G. M. (2003). The interplay of gender and affective tone in service encounter satisfaction. Journal of Service Research, 6(2), 136-143.

Meiren, T., \& Burger, T. (2010). Testing of service concepts. Service Industries Journal, 30 (4), 621-632.

Molina-Azorín, J. F., Tarí, J. J., Pereira-Moliner, J., Lopez-Gamero, M. D., \& PertusaOrtega, E. M. (2015). The effects of quality and environmental management on competitive advantage: A mixed methods study in the hotel industry. Tourism Management, 50, 41-54.

Neuendorf, K. A. (2017). The content analysis guidebook. Sage.

Nguyen, J., Ferraro, C., \& Sands, S. (2020). Similarity over difference: How congruency in customer characteristics drives service experiences. Journal of Business Research, 121(Dec), 592-603.

Nicholls, R. (2011). Customer-to-customer interaction (CCI): A cross-cultural perspective. International Journal of Contemporary Hospitality Management, 23(2) 209-223.

Nunnally, J. C. (1978). An overview of psychological measurement. Clinical diagnosis of mental disorders. Boston (MA): Springer.

Oliver, R. L. (1980). A cognitive model of the antecedents and consequences of satisfaction decisions. Journal of Marketing Research, 17(4), 460-469.

Osgood, C. E., \& Tannenbaum, P. H. (1955). The principle of congruity in the prediction of attitude change. Psychological Review, 62(1), 42.

Perdue, B. C., \& Summers, J. O. (1986). Checking the success of manipulations in marketing experiments. Journal of Marketing Research, 23(4), 317-326.

Qiu, H., Li, M., Shu, B., \& Bai, B. (2020). Enhancing hospitality experience with service robots: The mediating role of rapport building. Journal of Hospitality Marketing \& Management, 29(3), 247-268.

Redelmeier, D. A., \& Kahneman, D. (1996). Patients' memories of painful medical treatments: Real-time and retrospective evaluations of two minimally invasive procedures. Pain, 66(1), 3-8.

Rihova, I., Buhalis, D., Gouthro, M. B., \& Moital, M. (2018). Customer-to-customer cocreation practices in tourism: Lessons from customer-dominant logic. Tourism Management, 67, 362-375.

Ross, J., Irani, I., Silberman, M., Six Zaldivar, A., \& Tomlinson, B. (2010). Who are the crowdworkers? Shifting demographics in Amazon mechanical Turk. CHI EA 2010.

Ryan, G. W., \& Bernard, H. R. (2003). Techniques to identify themes. Field Methods, 15 (1), 85-109.

Seawright, K. K., \& Sampson, S. E. (2007). A video method for empirically studying waitperception bias. Journal of Operations Management, 25(5), 1055-1066.

So, K. K. F., Oh, H., \& Min, S. (2018). Motivations and constraints of Airbnb consumers: Findings from a mixed-methods approach. Tourism Management, 67, 224-236.

Spoor, J. R., \& Kelly, J. R. (2004). The evolutionary significance of affect in groups: Communication and group bonding. Group Processes \& Intergroup Relations, 7(4), 398-412.

Stylianou-Lambert, T. (2011). Gazing from home: Cultural tourism and art museums. Annals of Tourism Research, 38(2), 403-421.

Szymanski, D. M., \& Henard, D. H. (2001). Customer satisfaction: A meta-analysis of the empirical evidence. Journal of the Academy of Marketing Science, 29(1), 16.

Tajfel, H. (1981). Human groups and social categories: Studies in social psychology. Cup Archive.

Tickle-Degnen, L., \& Rosenthal, R. (1990). The nature of rapport and its nonverbal correlates. Psychological Inquiry, 1(4), 285-293.

Tsaur, S. H., Cheng, T. M., \& Hong, C. Y. (2019). Exploring tour member misbehavior in group package tours. Tourism Management, 71, 34-43.

Tsaur, S. H., \& Lin, W. R. (2014). Hassles of tour leaders. Tourism Management, 45, 28-38.

Tucker, L. R., \& Lewis, C. (1973). A reliability coefficient for maximum likelihood factor analysis. Psychometrika, 38(1), 1-10.

Verhoef, P. C., Antonides, G., \& De Hoog, A. N. (2004). Service encounters as a sequence of events: The importance of peak experiences. Journal of Service Research, 7(1), 53-64.

Victorino, L., \& Dixon, M. J. (2016). Testing service innovation: A methodological review of video experiments. Service Science, 8(2), 234-246.

Victorino, L., Verma, R., Bonner, B. L., \& Wardell, D. G. (2012). Can customers detect script usage in service encounters? An experimental video analysis. Journal of Service Research, 15(4), 390-400.

Viglia, G., \& Dolnicar, S. (2020). A review of experiments in tourism and hospitality. Annals of Tourism Research, 80, 102858.

Watson, W. E., Kumar, K., \& Michaelsen, L. K. (1993). Cultural diversity's impact on interaction process and performance: Comparing homogeneous and diverse task groups. Academy of Management Journal, 36(3), 590-602. 
Wu, C. H. J. (2007). The impact of customer-to-customer interaction and customer homogeneity on customer satisfaction in tourism service- the service encounter prospective. Tourism Management, 28(6), 1518-1528.

Wu, C. H. J. (2008). The influence of customer-to-customer interactions and role typology on customer reaction. Service Industries Journal, 28(10), 1501-1513.

Wu, L., Mattila, A. S., Wang, C. Y., \& Hanks, L. (2016). The impact of power on service customers' willingness to post online reviews. Journal of Service Research, 19(2), 224-238.

Yuksel, A., Kilinc, U., \& Yuksel, F. (2006). Cross-national analysis of hotel customers' attitudes toward complaining and their complaining behaviours. Tourism Management, 27(1), 11-24.

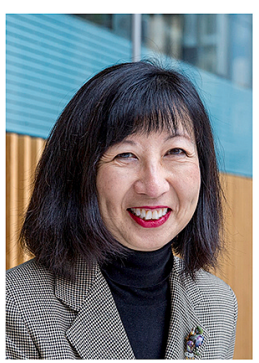

Linda W. Lee, Ph.D., is a Senior Lecturer at Nottingham Business School, Nottingham Trent University, UK. Her research interests include customer-customer interaction, the intersection of marketing and technology, and services marketing.

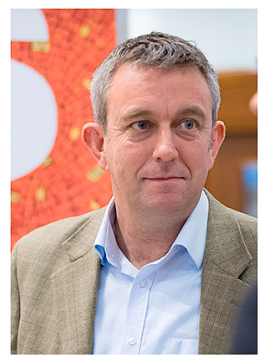

Ian P. McCarthy is the W.J. VanDusen Professor of Innovation \& Operations Management at Simon Fraser University and a professor at the Luiss Center in Leadership, Innovation and Organisation. His research interests include operations and innovation management. 